Kinetic and mechanistic study on the pyrolysis of 1,3-dihydroisothianaphthene-2,2-dioxide toward benzocyclobutene using RRKM and BET theories

Peer-reviewed author version

Zahedi Ehsan; Mozaffari Majid; Yousefi Leyla; SHIROUDI, Abolfazl \& DELEUZE, Michael (2017) Kinetic and mechanistic study on the pyrolysis of 1,3-dihydroisothianaphthene-2,2-dioxide toward benzocyclobutene using RRKM and BET theories. In: CHEMICAL PHYSICS, 483-484, p. 12-25.

DOI: 10.1016/j.chemphys.2016.11.005

Handle: http://hdl.handle.net/1942/22657 


\title{
Kinetic and mechanistic study on the pyrolysis of 1,3- dihydroisothianaphthene-2,2-dioxide toward benzocyclobutene using RRKM and BET theories
}

\author{
Ehsan Zahedi ${ }^{a, *}$, Majid Mozaffari $^{a}$, Leyla Yousefi $^{a}$, Abolfazl Shiroudi $^{b}$, Michael S. Deleuze $^{b}$ \\ ${ }^{a}$ Chemistry Department, Shahrood Branch, Islamic Azad University, Shahrood, Iran \\ ${ }^{b}$ Center of Molecular and Materials Modelling, Hasselt University, Agoralaan, Gebouw D, B-3590 Diepenbeek, Belgium
}

\begin{abstract}
The kinetics and mechanisms of pyrolysis of 1,3-dihydroisothianaphthene-2,2-dioxide toward benzocyclobutene have been theoretically studied using canonical transition state theory (CTST), statistical Rice-Ramsperger-Kassel-Marcus (RRKM) theory, and bonding evolution theory (BET) in conjugation with M06-2X/aug-cc-pVTZ calculations. The CTST slightly breaks down to estimate the reaction rate of the cheletropic extrusion. RRKM results indicated that the cheletropic extrusion and electrocyclic reaction require energy barriers of 171.3 and 122.2 $\mathrm{kJ} / \mathrm{mol}$ to be overcome; and can be characterized respectively by 7 and 3 phases associated to the sequence of catastrophes $\mathrm{C}_{8} \mathrm{H}_{8} \mathrm{SO}_{2}(\mathbf{1}): 7-[\mathrm{FF}] \mathrm{C}^{\dagger} \mathrm{C}^{\dagger} \mathrm{FFF}-0: \mathrm{C}_{8} \mathrm{H}_{8}+\mathrm{SO}_{2}$ and $\mathrm{C}_{8} \mathrm{H}_{8}(\mathbf{2}): 3-\left[\mathrm{F}^{\dagger} \mathrm{F}^{\dagger}\right] \mathrm{C}-$ $0: \mathrm{C}_{8} \mathrm{H}_{8}(3)$. For the cheletropic extrusion, breaking of the $\mathrm{C}_{7}-\mathrm{S}$ and $\mathrm{C}_{8}-\mathrm{S}$ bonds begins respectively at $\mathrm{Rx}=-2.7434 \mathrm{amu}^{1 / 2} \mathrm{Bohr}$ and $\mathrm{Rx}=-1.7458 \mathrm{amu}^{1 / 2} \mathrm{Bohr}$, and formation of the sulfur dioxide is completed at $\mathrm{Rx}=-0.2494 \mathrm{amu}^{1 / 2}$ Bohr. For the electrocyclic reaction, formation of new $\mathrm{C}_{7}-\mathrm{C}_{8}$ bond occurs at $\mathrm{Rx}=1.6214 \mathrm{amu}^{1 / 2} \mathrm{Bohr}$ from $\mathrm{C}$ - to $\mathrm{C}$ - coupling between the generated pseudoradical centers at $\mathrm{Rx}=0.1474 \mathrm{amu}^{1 / 2} \mathrm{Bohr}$ on the terminal carbon atoms.
\end{abstract}

Keywords: Cheletropic extrusion; Electrocyclic reaction; CTST; RRKM theory; BET; ELF

\footnotetext{
* Corresponding author. Tel: +98 912 2733755; Fax: +98 2332344634

E-mail addresses: e_zahedi@iau-shahrood.ac.ir; e_zahedi1357@yahoo.com
} 


\section{Introduction}

From the molecular physical chemist's viewpoint, the most interesting aspects of a reaction are its reaction rates and the underlying mechanisms. Rate constant of an elementary reaction can be estimated from classical trajectory methods or statistical theories such as transition state theory (TST) or Rice-Ramsperger-Kassel-Marcus (RRKM) theory [1]. In a broad sense, a reaction mechanism is a step by step sequence of individual collisional or other elementary reactions leading to the overall chemical change whose kinetics is under study [2]. In the present work, the reaction mechanism is inferred from a detailed analysis of bond breaking/forming and charge redistribution along the channel connecting reactants to products via the transition state and possible intermediates [3, 4], using bonding evolution theory (BET), which combines topological analysis of the electron localization function (ELF) $[5,6]$ with the Rene Thom's catastrophe theory (CT) [7]. The concept of BET was proposed by Krokidis et al. [8] and allows to perceive electronic rearrangement and bonding changes taking place along a reaction path. An important class of organic reactions pertains to pericyclic reactions, which imply a reorganization of $\sigma$ and $\pi$ bonds through a cyclic transition structure. Woodward and Hoffmann proposed that pericyclic reactions involve concerted reorganization of electrons within a closed curve of interacting orbitals [9]. The pericyclic reactions can be classified as cycloaddition and cheletropic, elimination, electrocyclic, ene (group transfer), sigmatropic, and dyotropic reactions. The first use of BET for characterizing bonding changes along an elementary reaction dates back to S. Berski et al. [10] in 2003. They studied the decay and formation of bonds along the intrinsic reaction coordinate (IRC) of the Diels-Alder cycloaddition between ethylene and 1,3-butadiene. They also showed that ring closure through a formation of two new sigma $\mathrm{C}-\mathrm{C}$ bonds begins after the formation of the transition state. Topological analysis of Diels-Alder cycloaddition between ethylene and 1,3-butadiene reveals that breaking of three $\mathrm{C}=\mathrm{C}$ double bonds begin at the first stage of reaction. After passing the transition state point the formation of four pseudoradical centers at the end carbons occurs, and then formation of two new single $\mathrm{C}-\mathrm{C}$ bonds takes place from coupling of pseudoradical centers. At the end of the reaction, when the formation of single $\mathrm{C}-\mathrm{C}$ bonds are completed, formation of a new $\mathrm{C}=\mathrm{C}$ double bond begins [11]. So far, the molecular mechanisms and bonding changes of a wide range of chemical reactions including the Diels-Alder cycloaddition [4, 11-20] and 1,3 dipolar cycloaddition [20-24] reactions, Bergman cyclization [25], Cope rearrangement [3], Friedel-Crafts reaction [26], Staudinger reaction [27, 
28], ene reaction [29, 30], ring cleavage reaction [31], trimerization reaction [32], and [2+2] cycloaddition $[33,34]$ reaction have been studied using BET. The molecular mechanisms of cheletropic reactions have received so far little attention. According to the rules by WoodwardHoffmann, the cheletropic reactions are a special group of cycloadditions in which two $\sigma$ bonds are being created between the terminal atoms of a fully conjugated system and a single atom in a concerted process [35]. The reverse direction of a cheletropic reaction, in which a simple stable molecule such as $\mathrm{CO}, \mathrm{N}_{2}, \mathrm{~N}_{2} \mathrm{O}$ or $\mathrm{SO}_{2}$ is eliminated, is referred to as a cheletropic extrusion process, which can be described as a unimolecular thermal elimination process (see scheme 1).

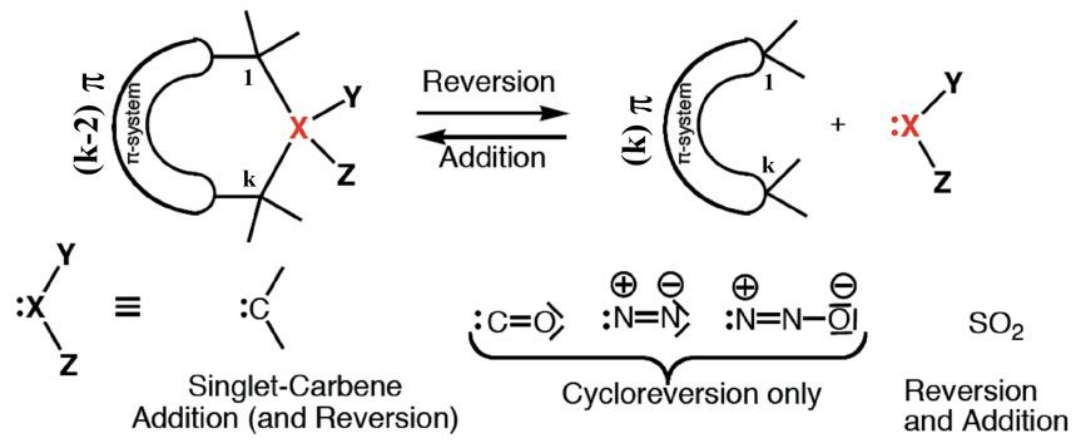

Scheme 1

In our preceding work [36] we reported a mechanistic study of a cheletropic reaction, namely the thermal elimination of $\mathrm{N}_{2}$ from (2,5-dihydro-1H-pyrrol-1-ium-1-ylidene). RRKM calculations of unimolecular rate constants revealed that transition state theory slightly breaks down at 1.0 atm, hence the kinetic model must account for fall-off effects. BET analysis of this reaction showed that the topological changes along the reaction path occur in the vicinity of the transition state.

Gas phase pyrolysis of 1,3-dihydroisothianaphthene-2,2-dioxide (compound 1) to benzocyclobutene (compound 3) via o-quinodimethane (compound 2) is a complex process including an electrocyclic reaction (scheme 2), preceded by a cheletropic extrusion which has been studied experimentally by Cava and Deana [37] (see scheme 3). They pyrolyzed compound 1 in the vapor phase at temperature ranging from 733 to $1043 \mathrm{~K}$ in a low pressure nitrogen atmosphere. At temperatures of 733, 833, and $943 \mathrm{~K}$, the percentage yields of compound $\mathbf{3}$ were found to be 60,59 , and $63 \%$, respectively. When the temperature of the heating coil was raised to $1043 \mathrm{~K}$, compound 3 was obtained in $67 \%$ yield. 


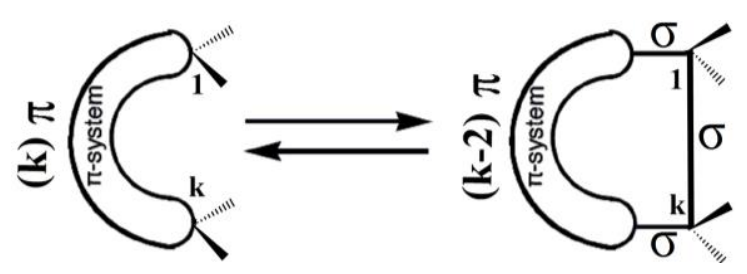

Scheme 2

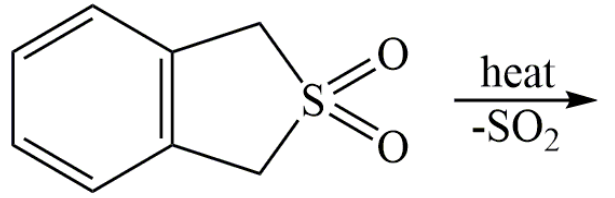

1,3-dihydroisothianaphthene-2,2-dioxide

(1)

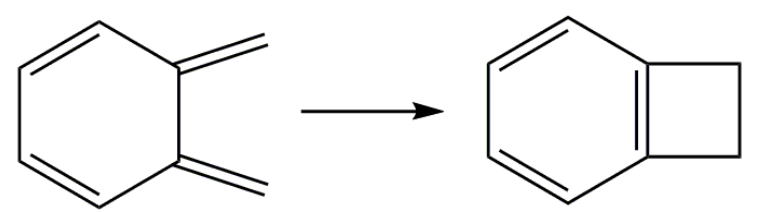

benzocyclobutene

(3)

Scheme 3

In spite of the fact that a long time elapsed from the first report of the above reaction, its kinetic and the underlying molecular mechanisms have still not been investigated, and will be the subject of the present study. In this work, unimolecular rate constants for the cheletropic extrusion and electrocyclic reaction will be supplied in the high pressure limit and in the fall-off regime by means of TST [38-40] and statistical RRKM [41-44] theory, for the purpose of unraveling the experiments by Cava et al. [37] at 733, 833, 943, and $1043 \mathrm{~K}$. In addition, topological analysis of bond breaking/formation along the reaction coordinates is implemented using the ELF and BET approaches in order to establish which molecular mechanisms are associated with these reactions.

\section{Computational details}

The geometries of the reactant, products, intermediate, and transition states involved in the formation of compound $\mathbf{3}$ from the pyrolysis of compound $\mathbf{1}$ are optimized using the GEDIIS optimizer [45] of Berny algorithm using density functional theory (DFT) along with the M06-2X hybrid functional of Zhao and Truhlar [46, 47] in conjugation with Dunning's correlationconsistent basis set of triple- $\zeta$ quality augmented with diffuse functions (aug-cc-pVTZ basis set) [48]. The M06-2X is among the best exchange-correlation functional for applications involving main-group thermochemistry, kinetics, noncovalent interactions, and electronic excitation 
energies to valence and Rydberg states [46]. The nature of all identified stationary points were determined according to the calculations of harmonic vibrational frequencies; energy minima possess an Hessian matrix with no negative eigenvalues, while transition states were identified by having one and only one negative eigenvalue associated with the motion of atoms over the saddle point. Moreover, IRC calculations were carried out in both directions (forward and backward) using the Hessian based predictor corrector (HPC) integrator algorithm to verify that the energy profiles connect each saddle point to the relevant reactant and product(s). Global electron-density transfer (GEDT) between the two frameworks involved in the cheletropic extrusion step is evaluated using the natural population analysis [49]. All electronic structure calculations that are discussed in the present work were carried out using the Gaussian 09 package of programs [50]. Thermodynamic properties and unimolecular kinetic rate constants are obtained using the implementation of canonical transition state theory (CTST) and statistical RRKM theory in the Kinetic and Statistical Thermodynamical Package (KiSThelP) [51]. Kinetic rate constants for the cheletropic extrusion and electrocyclic reaction at experimental temperatures $733,833,943$, and $1043 \mathrm{~K}$ are calculated using canonical transition state theory which is conventionally called the high-pressure limit for a unimolecular reaction [52]. The rate constants for unimolecular reactions are therefore given by [43]:

$k_{\mathrm{TST}}(T)=\kappa(T) \times \frac{\sigma k_{\mathrm{B}} T}{h} \times \frac{Q^{\dagger}}{Q_{\mathrm{R}}} \times \exp \left(-E^{\dagger} / k_{\mathrm{B}} T\right)$

In the above equation, $k_{\mathrm{B}}$ and $h$ are respectively the Boltzmann's and Planck's constants, $\sigma$ denotes the reaction path degeneracy, $\kappa(T)$ is the relevant tunneling correction factor, $T$ is the absolute temperature, and $E^{\dagger}$ is the threshold energy, defined as the difference between zeropoint energies of the transition state and the reactant. $Q_{\mathrm{R}}$ is the complete canonical partition function per unit volume for reactant and $Q^{\dagger}$ is the partition function for all the degrees of freedom of the TS except that of the reaction coordinate. Rotational symmetry numbers are not included in the partition function and multiplied separately as reaction symmetry number in the calculation of the rate constants. According to the point groups of symmetries of the all stationary points, the reaction symmetry number $\sigma=1$ is taken into consideration for the cheletropic extrusion and electrocyclic reaction. The unsymmetrical Eckart potential function is used to correct the theoretically determined TST rate constants. Quantum mechanical tunneling correction is calculated based on the unsymmetrical Eckart potential energy barrier by 
numerically integrating the transmission probability $p(E)$ of tunneling through the corresponding 1-dimensional (1D) barrier at energy $E$ over a Boltzmann distribution of energies [53]:

$$
\kappa_{\text {Eckart }}(T)=\frac{\exp \left(\Delta H_{\mathrm{f}}^{\dagger, 0 \mathrm{~K}} / k_{\mathrm{B}} T\right)}{k_{\mathrm{B}} T} \int_{\mathrm{o}}^{\infty} p(E) \exp \left(-E / k_{\mathrm{B}} T\right) \mathrm{d} E
$$

where $p(E)$ depends on $E$ and three other parameters which are determined by the shape of the barrier and an effective mass for the system [54], and $\Delta H_{\mathrm{f}}^{\dagger, 0 \mathrm{~K}}$ is the zero-point corrected energy barrier in the forward direction.

The fall-off behavior of canonical kinetic rate constants from the CTST limit $(P \rightarrow \infty)$ towards the low-pressure limit $(P \rightarrow 0)$ has been also studied at the experimentally employed temperatures 733, 833, 943, and $1043 \mathrm{~K}$ using statistical RRKM theory [44, 55, 56].The energy-dependent microcanonical rate constants $k(E)$ are given by the standard RRKM expression [44]:

$k(E)=\frac{\sigma N^{\dagger}(E)}{h \rho(E)}$

where $\rho(E)$ represents the density of states at the reactants, and $N^{\dagger}(E)$ denotes the total number of states at the transition state with energy less than or equal to $E$. Canonical RRKM rate constants $\mathrm{k}(\mathrm{T})$ are then ultimately determined by state integration and Boltzmann averaging:

$$
k(T)=\int_{E_{\mathrm{o}}}^{\infty} f(E, T) k(E) d E
$$

along with:

$$
f(E, T)=\frac{1}{Q(T)} \rho(E) \exp (-\beta E)
$$

where $\beta=1 / k_{\mathrm{B}} T$ and $Q(T)$ is the reactant partition function:

$$
Q(T)=\int_{0}^{\infty} \rho(E) \exp (-\beta E) d E
$$

Lennard-Jones (LJ) collision rate theory was used to evaluate collisional stabilization rate constants. The Lennard-Jones collision frequencies $\left(Z_{\mathrm{LJ}}\right)$ are calculated from the following Lennard-Jones potential parameters: $\sigma=3.738 \AA, \varepsilon / k_{\mathrm{B}}=82.0 \mathrm{~K}$ for $\mathrm{N}_{2}$ [57], $\sigma=6.2 \AA, \varepsilon / k_{\mathrm{B}}=$ $528.6 \mathrm{~K}$ for compound 1 , and $\sigma=5.7 \AA, \varepsilon / k_{\mathrm{B}}=486.7 \mathrm{~K}$ for compound 2 [58]. For all RRKM calculations, we assumed that every collision deactivates with effective collision frequency 
$\omega=\beta_{\mathrm{c}} \cdot \mathrm{Z}_{\mathrm{LJ}} \cdot[\mathrm{M}]$, where collisional efficiency $\beta_{\mathrm{c}}=0.2$ and $[\mathrm{M}]$ represents the total gas concentration [59].

The topological analysis of the ELF was performed for all the selected structures along the reaction coordinates by means of the TopMod program [60] and the Multiwfn suite of tools [61] upon M06-2X/aug-cc-pVTZ monodeterminantal wavefunctions, in order to characterize the critical points according to the BET analysis and to determine the successive structural stability domains (SSDs) along the reaction coordinates.

For a single determinental wavefunction, spherically averaged like-spin conditional pair probability has direct correlation with the Fermi hole, and the ELF (Electron Localization Function) can be given by equations 7-9 [61]:

$$
\begin{aligned}
& \operatorname{ELF}=\eta(\mathbf{r})=\frac{1}{1+\left(D_{\sigma}(\mathbf{r}) / D_{\sigma}^{\mathrm{o}}(\mathbf{r})\right)^{2}} \\
& D_{\sigma}(\mathbf{r})=\frac{1}{2} \sum_{i}^{\mathrm{Occ}}\left|\nabla \phi_{\mathrm{i}}\right|^{2}-\frac{1}{8}\left[\frac{\left|\nabla \rho_{\alpha}(\mathbf{r})\right|^{2}}{\rho_{\alpha}(\mathbf{r})}+\frac{\left|\nabla \rho_{\beta}(\mathbf{r})\right|^{2}}{\rho_{\beta}(\mathbf{r})}\right] \\
& D_{\sigma}^{\mathrm{o}}(\mathbf{r})=\frac{3}{10}\left(6 \pi^{2}\right)^{2 / 3}\left[\rho_{\alpha}(\mathbf{r})^{5 / 3}+\rho_{\beta}(\mathbf{r})^{5 / 3}\right]
\end{aligned}
$$

where the sum is over all singly occupied one-electron (spin-) orbitals $\phi_{\mathrm{i}}$ in an N electron system, $0 \leq \mathrm{ELF} \leq 1, D_{\sigma}(\mathbf{r})$ has the physical meaning of the excess of local kinetic energy density due to Pauli's repulsion, and $D_{\sigma}^{0}(\mathbf{r})$ is the Thomas-Fermi kinetic energy density, which can be regarded as a renormalization factor. When two electrons are paired with antiparallel spin in space, the ELF will be large $[8,61,62]$. Based on the topological analysis of the ELF a partition of the geometrical molecular space can be achieved into basins of attractors. According to the dynamical system theory, the points corresponding to the local maxima of ELF are called attractors. The basin of an attractor is a region of space containing the points by which a steepest ascent leads to the attractor. These basins are either classified into core basins, $\mathrm{C}(\mathrm{A})$, surrounding nuclei with atomic number $Z>2$, and valence basins in the remaining space that are characterized by the number of atomic valence shells, also referred to as synaptic order, to which they participate. According to the synaptic order the valence basins can be classified into monosynaptic basins, labelled V(A), which correspond to lone pairs or non-bonding regions, disynaptic basins, labelled $\mathrm{V}(\mathrm{A}, \mathrm{B})$, which correspond to two-center bonds, trisynaptic basins, 
labeled $\mathrm{V}(\mathrm{A}, \mathrm{B}, \mathrm{C})$, which correspond to three-center bonds and so on $\mathrm{V}(\mathrm{A}, \mathrm{B}, \mathrm{C}, \ldots$ ) for higher polysynaptic basins $[8,19,63]$.

The average population for an ELF topological basin $\Omega_{i}$ is defined by the integrated density in the basin region [64]:

$$
\bar{N}\left(\Omega_{i}\right)=\int_{\Omega_{i}} \rho(\mathbf{r}) \mathrm{d} \mathbf{r}
$$

According to the type of attractor in the basin region, the average population can be referred to core, bonding and non-bonding electron populations.

Topological changes along the cheletropic extrusion and electrocyclic reaction is represented by the more informative sequence of catastrophes belonging exclusively to the fold ( $\mathrm{F}$ and $\mathrm{F}^{\dagger}$ ) and cusp $\left(\mathrm{C}\right.$ and $\left.\mathrm{C}^{\dagger}\right)$ elementary types. A C (or F) catastrophe merges two attractors (an attractor) and a saddle point into an attractor (a wandering point) which leads to a decrease of the number of basins by $1 . \mathrm{A} \mathrm{C}^{\dagger}$ (or $\mathrm{F}^{\dagger}$ ) catastrophe splits an attractor (a wandering point) into two attractors (an attractor) and a saddle point which leads to an increase of the number of basins [4, 34].

\section{Results and discussion}

\subsection{Geometrical characteristics and rate constant calculations}

Analysis of the intrinsic reaction coordinates indicates that breaking of two $\mathrm{C}_{7}-\mathrm{S}$ and $\mathrm{C}_{8}-\mathrm{S}$ single bonds in the cheletropic extrusion and formation of a $\mathrm{C}_{7}-\mathrm{C}_{8}$ single bond in the electrocyclic reaction take place through two one-step processes. The optimized geometries of all identified stationary points involved in the cheletropic extrusion and electrocyclic reaction is supplied in Table 1 at the M06-2X/aug-cc-pVTZ level of theory. The reader is correspondingly referred to Figure 1 for detailed atom labelling.

For compound $\mathbf{1}$, the $\mathrm{C}_{7}-\mathrm{S}$ and $\mathrm{C}_{8}-\mathrm{S}$ bond lengths are $1.808 \AA$. The length of the breaking $\mathrm{C}_{7}-\mathrm{S}$ and $\mathrm{C}_{8}-\mathrm{S}$ single bonds within the transition state TS1 associated with the cheletropic extrusion are 2.609 and $2.400 \AA$, respectively, meaning that the bond breaking process is concerted but asynchronous. For compound $\mathbf{2}$, the $\mathrm{C}_{1}-\mathrm{C}_{7}$ and $\mathrm{C}_{2}-\mathrm{C}_{8}$ bond lengths are $1.339 \AA$, while the $\mathrm{C}_{7}-\mathrm{C}_{1}-\mathrm{C}_{2}-\mathrm{C}_{8}$ dihedral angle is $23^{\circ}$. 
Table 1. Structural parameters for all stationary points involved in the cheletropic extrusion and electrocyclic reaction optimized at the M06-2X/aug-cc-pVTZ level of theory

\begin{tabular}{lccccc}
\hline Parameter $^{\mathrm{a}}$ & $\mathbf{1}$ & TS1 & $\mathbf{2}$ & TS2 & $\mathbf{3}$ \\
\hline$r\left(\mathrm{C}_{1}-\mathrm{C}_{2}\right)$ & 1.396 & 1.447 & 1.487 & 1.410 & 1.386 \\
$r\left(\mathrm{C}_{2}-\mathrm{C}_{3}\right)$ & 1.386 & 1.431 & 1.461 & 1.408 & 1.380 \\
$r\left(\mathrm{C}_{3}-\mathrm{C}_{4}\right)$ & 1.386 & 1.354 & 1.338 & 1.372 & 1.395 \\
$r\left(\mathrm{C}_{4}-\mathrm{C}_{5}\right)$ & 1.389 & 1.428 & 1.455 & 1.418 & 1.394 \\
$r\left(\mathrm{C}_{5}-\mathrm{C}_{6}\right)$ & 1.386 & 1.351 & 1.338 & 1.372 & 1.395 \\
$r\left(\mathrm{C}_{6}-\mathrm{C}_{1}\right)$ & 1.386 & 1.436 & 1.461 & 1.408 & 1.380 \\
$r\left(\mathrm{C}_{1}-\mathrm{C}_{7}\right)$ & 1.501 & 1.376 & 1.339 & 1.413 & 1.515 \\
$r\left(\mathrm{C}_{2}-\mathrm{C}_{8}\right)$ & 1.501 & 1.385 & 1.339 & 1.413 & 1.515 \\
$r\left(\mathrm{C}_{7}-\mathrm{C}_{8}\right)$ & - & - & - & 2.269 & 1.570 \\
$r\left(\mathrm{C}_{7}-\mathrm{S}\right)$ & 1.808 & 2.609 & - & - & - \\
$r\left(\mathrm{C}_{8}-\mathrm{S}\right)$ & 1.808 & 2.400 & - & - & - \\
$r\left(\mathrm{~S}-\mathrm{O}_{1}\right)$ & 1.449 & 1.445 & - & - & - \\
$r\left(\mathrm{~S}-\mathrm{O}_{2}\right)$ & 1.448 & 1.446 & - & - & - \\
$\theta\left(\mathrm{O}_{2}-\mathrm{S}-\mathrm{O}_{1}\right)$ & 119.91 & 117.11 & - & - & - \\
$\theta\left(\mathrm{C}_{7}-\mathrm{S}-\mathrm{C}_{8}\right)$ & 94.85 & 68.99 & - & - & - \\
$\theta\left(\mathrm{C}_{7}-\mathrm{C}_{1}-\mathrm{C}_{2}-\mathrm{C}_{8}\right)$ & 0.00 & 0.76 & 23.00 & 24.81 & 0.00 \\
\hline
\end{tabular}

${ }^{a}$ Bond lengths are in angstrom $(\AA)$, torsion and dihedral angles are in degrees $\left({ }^{\circ}\right)$.

The transition state TS2 associated with the electrocyclic reaction of the compound 2 into compound 3 is characterized by $\mathrm{C}_{1}-\mathrm{C}_{7}$ and $\mathrm{C}_{2}-\mathrm{C}_{8}$ bond lengths of $1.413 \AA$; and by a dihedral angle $\mathrm{C}_{7}-\mathrm{C}_{1}-\mathrm{C}_{2}-\mathrm{C}_{8}$ of $24.81^{\circ}$. This step is associated with a shortening of the $\mathrm{C}_{7}-\mathrm{C}_{8}$ distance from 2.269 to $1.570 \AA$, while the $\mathrm{C}_{7}-\mathrm{C}_{1}-\mathrm{C}_{2}-\mathrm{C}_{8}$ dihedral angle reduces to zero. Based on geometrical properties and the point group symmetry of all stationary points, the rotational symmetry numbers are one for compound $\mathbf{1}$ and two for TS1 and compound $\mathbf{2}$.

The GEDT value for the transferred electron density from the diene moiety toward $\mathrm{SO}_{2}$ at the TS1 is $0.04 \bar{e}$. This value allows classifying the cheletropic extrusion as a non-polar reaction. The predicted unscaled harmonic vibrational frequencies and rotational moments of inertia for all stationary points involved in the cheletropic extrusion and electrocyclic reaction is summarized respectively in Tables 2 and 3. In all calculations a scaling factor of 0.956 was applied to the M06-2X/aug-cc-pVTZ harmonic frequencies in order to partially account for anharmonic effects [65]. 


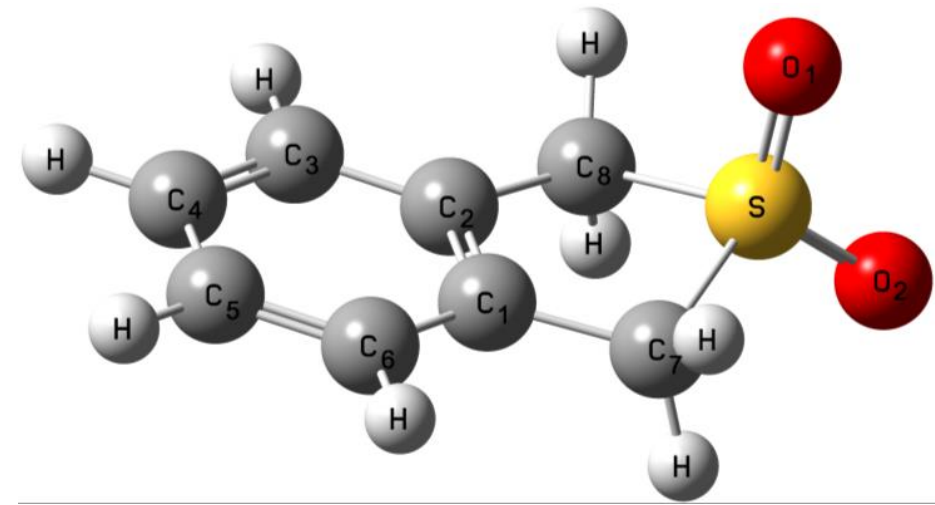

1

1,3-dihydroisothianaphthene-2,2-dioxide

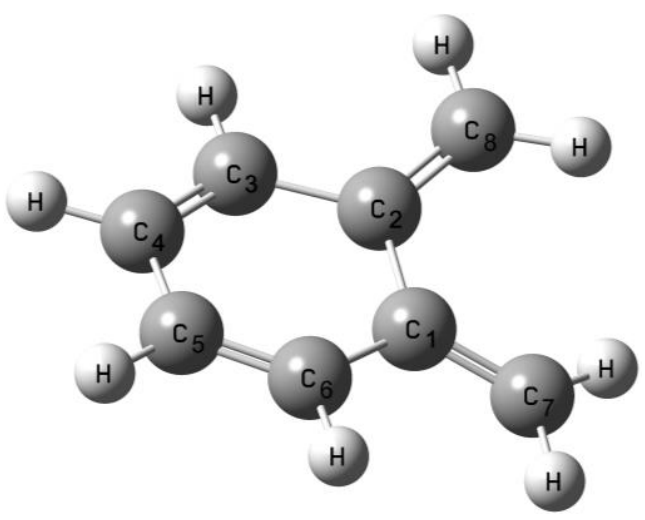

2

$o$-quinodimethane

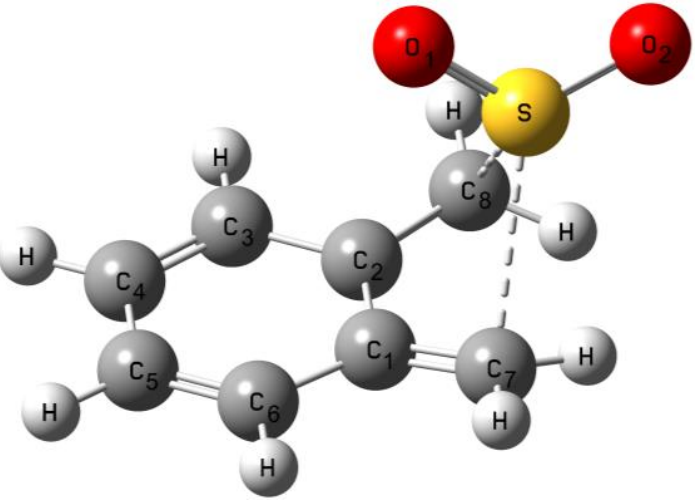

TS1

Associated with the cheletropic extrusion

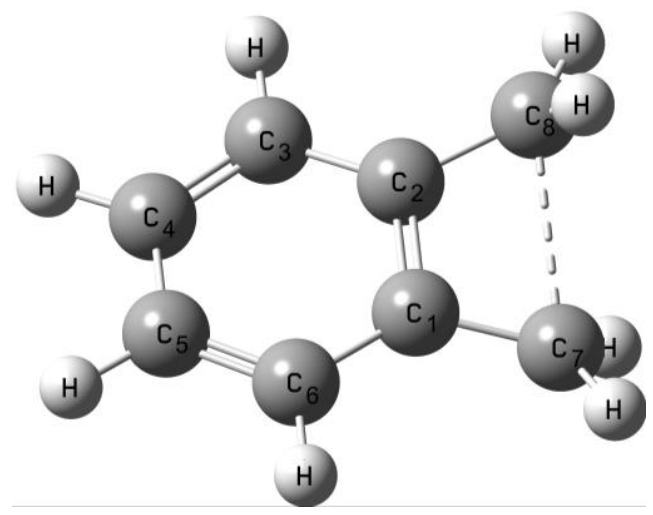

TS2

Associated with the electrocyclic reaction

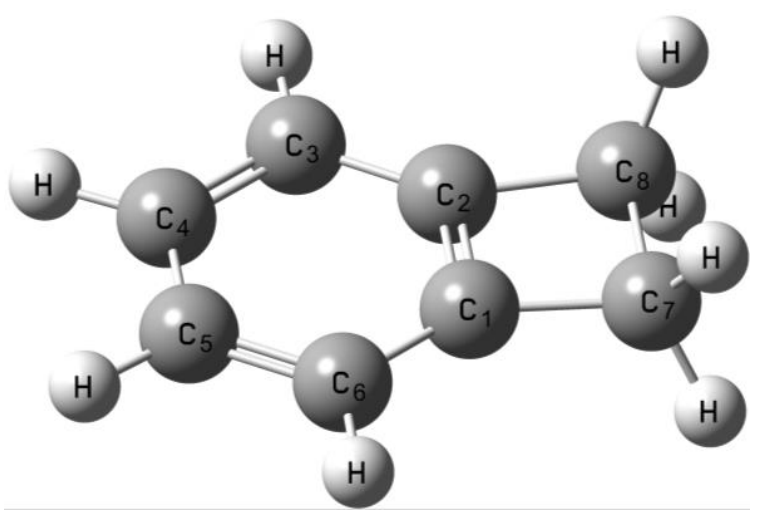

3

benzocyclobutene

Figure 1. Geometries of all stationary points involved in the cheletropic extrusion and electrocyclic reaction optimized at the M06-2X/aug-cc-pVTZ level of theory. 
Table 2. Unscaled harmonic vibrational frequencies and rotational moments of inertia calculated at the M06-2X/aug-cc-pVTZ level of theory for cheletropic extrusion

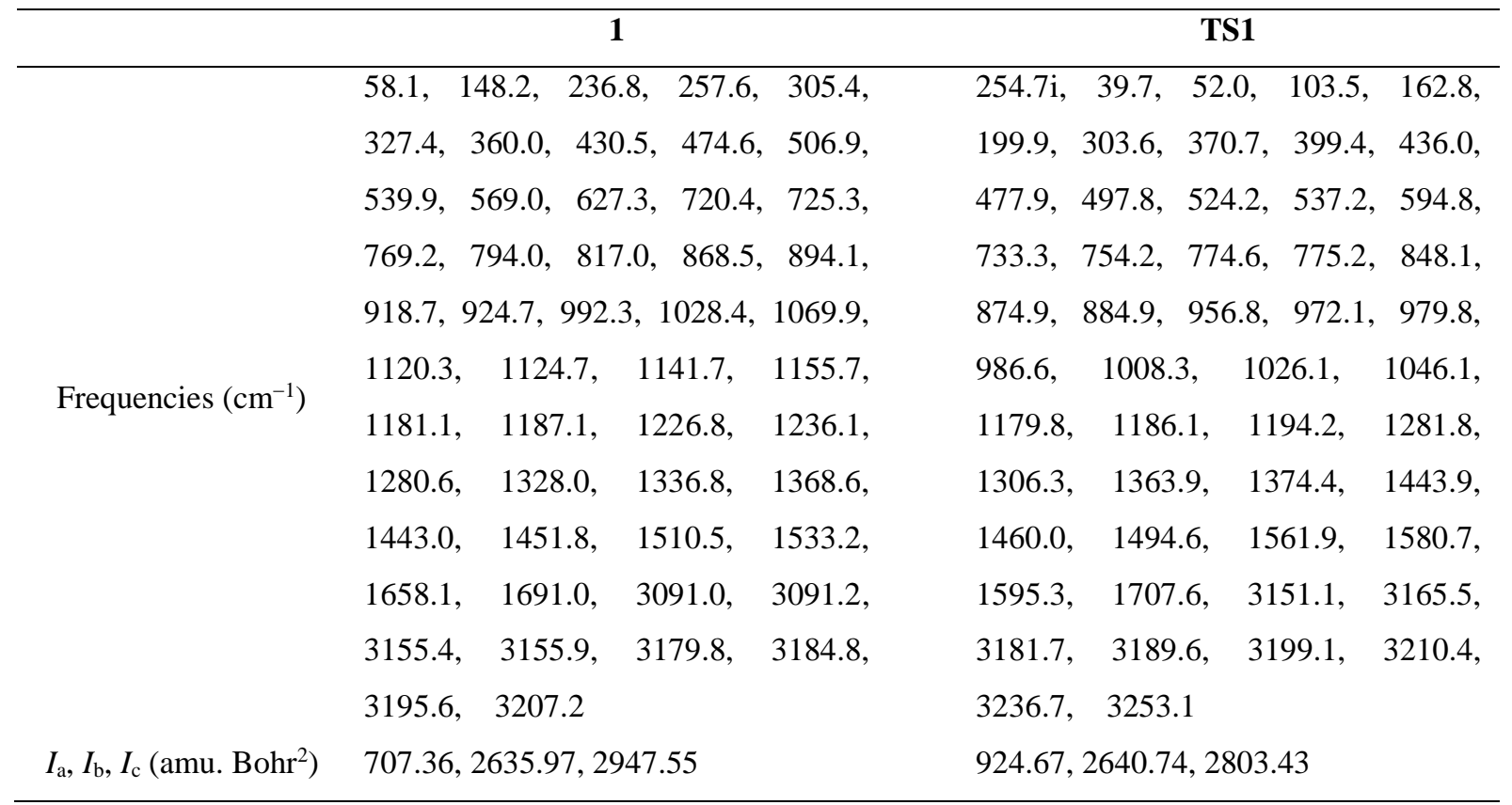

Table 3. Unscaled harmonic vibrational frequencies and rotational moments of inertia calculated at the M06-2X/aug-cc-pVTZ level of theory for electrocyclic reaction

\begin{tabular}{|c|c|c|}
\hline & 2 & TS2 \\
\hline \multirow{10}{*}{ Frequencies $\left(\mathrm{cm}^{-1}\right)$} & $82.4, \quad 229.5, \quad 356.4, \quad 409.9, \quad 431.9$, & $655.0 \mathrm{i}, \quad 224.7, \quad 227.9, \quad 391.2, \quad 428.7$, \\
\hline & $434.1, \quad 517.3, \quad 586.0,658.9, \quad 707.9$, & $528.1, \quad 575.3, \quad 596.2, \quad 667.2, \quad 682.4$, \\
\hline & $741.3,761.9,814.9,852.3,874.5$, & 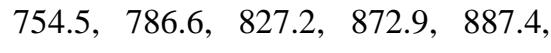 \\
\hline & 940.1, 943.1, 964.4, 971.5, 1012.4, & 912.4, 918.4, 983.9, 1013.0, 1013.5, \\
\hline & 1016.7, $1019.7, \quad 1186.9, \quad 1187.5$, & 1020.8, $\quad 1041.7, \quad 1151.1$ \\
\hline & $1263.5, \quad 1342.9, \quad 1378.4$ & $1242.6, \quad 1334.6, \quad 1359.4$ \\
\hline & $1478.6, \quad 1636.3$ & $1475.8, \quad 1494.2, \quad 1526.4$ \\
\hline & $1739.1, \quad 3153.7$ & 1608.1 \\
\hline & $3177.4, \quad 3181.1, \quad 3197.6$ & $3178.4, \quad 3186.0, \quad 3196.4$ \\
\hline & $3241.4,3245.5$ & $3249.2,3249.4$ \\
\hline$I_{\mathrm{a}}, I_{\mathrm{b}}, I_{\mathrm{c}}\left(\mathrm{amu} . \mathrm{Bohr}^{2}\right)$ & $566.38,750.92,1294.09$ & $470.19,805.99,1229.19$ \\
\hline
\end{tabular}


Table 4. The reaction Gibbs free energies, reaction enthalpies, and reaction entropies of the cheletropic extrusion calculated at the M06-2X/aug-cc-pVTZ level of theory at $P=1$ atm

\begin{tabular}{cccc}
\hline$T(\mathrm{~K})$ & $\Delta G(\mathrm{~kJ} / \mathrm{mol})$ & $\Delta H(\mathrm{~kJ} / \mathrm{mol})$ & $\Delta S(\mathrm{~J} / \mathrm{mol} . \mathrm{K})$ \\
\hline 733 & 18.2 & 157.8 & 190.4 \\
833 & -0.71 & 156.6 & 188.8 \\
943 & -21.3 & 155.1 & 187.2 \\
1043 & -40.0 & 153.7 & 185.8 \\
\hline
\end{tabular}

Table 5. The reaction Gibbs free energies, reaction enthalpies, and reaction entropies of the electrocyclic reaction calculated at the M06-2X/aug-cc-pVTZ level of theory at $P=1$ atm

\begin{tabular}{cccc}
\hline$T(\mathrm{~K})$ & $\Delta G(\mathrm{~kJ} / \mathrm{mol})$ & $\Delta H(\mathrm{~kJ} / \mathrm{mol})$ & $\Delta S(\mathrm{~J} / \mathrm{mol} . \mathrm{K})$ \\
\hline 733 & -48.9 & -64.5 & -21.3 \\
833 & -46.8 & -64.8 & -21.6 \\
943 & -44.4 & -65.1 & -21.9 \\
1043 & -42.2 & -65.2 & -22.0 \\
\hline
\end{tabular}

The reader is referred to Figure 2, Tables 4 and 5 for the relative enthalpies, entropies and Gibbs free energies of the cheletropic extrusion and electrocyclic reaction at a pressure of $1 \mathrm{~atm}$ and at the experimentally employed temperatures of 733, 833, 943, and $1043 \mathrm{~K}$.

The cheletropic extrusion of $\mathrm{SO}_{2}$ from compound $\mathbf{1}$ is strongly endothermic and characterized by a sharp increase in entropy. The endothermic character of the cheletropic extrusion may be due to the loss of aromaticity within a benzene ring along the elimination process. Entropy effects make the compound $\mathbf{2}$ thermally more stable than compound $\mathbf{1}$ at temperatures higher than $833 \mathrm{~K}$ (Table 4). Therefore, the cheletropic extrusion at these temperatures can takes place as a spontaneous process. Comparison of above results with desulfonylation of dinitro-substituted derivative of compound 1 represents invaluable information. Desulfonylation of Z- and E-2,5dinitro-3,4-dimethyl-thiolene 1,1-dioxides has been studied theoretically by Jasiński et al. [66] in the gas phase and in the presence of toluene and nitromethane. They showed that the cheletropic extrusion of $\mathrm{SO}_{2}$ from dinitro-substituted derivative of compound $\mathbf{1}$ at ambient temperature is highly exothermic and spontaneous process, while for non-substituted compound $\mathbf{1}$ is endothermic and non-spontaneous. It can be concluded that the cheletropic extrusion reaction of compound 1 is highly sensitive to the substituent of functional groups. 

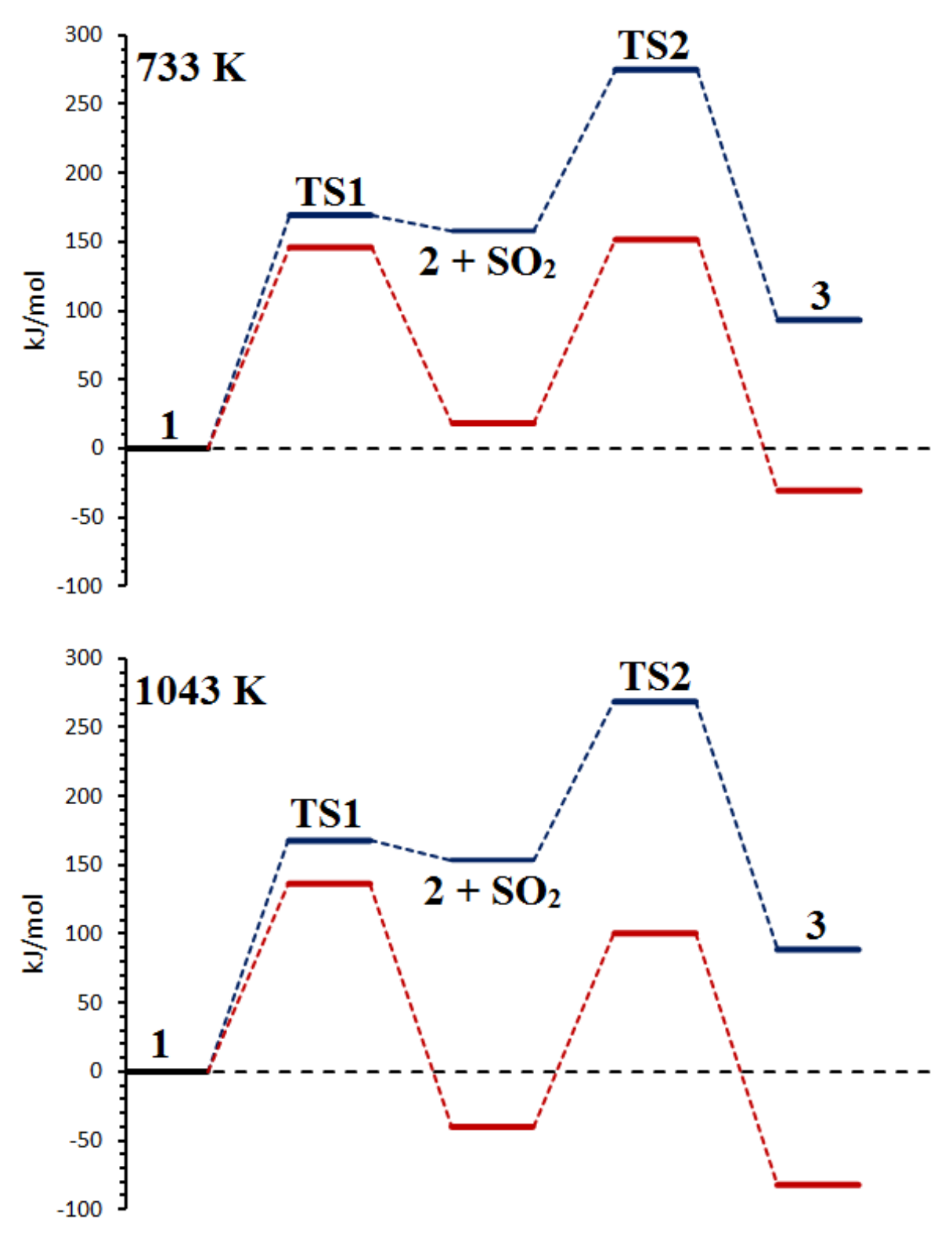

Figure 2. Gibbs free energy (red lines) and enthalpy (blue lines) profiles for the cheletropic extrusion and electrocyclic reaction calculated at the M06-2X/aug-cc-pVTZ level of theory and $T$ $=733$ and $1043 \mathrm{~K}$.

Electrocyclic reaction of compound $\mathbf{2}$ toward compound $\mathbf{3}$ is thermodynamically favored and the reaction is strongly exothermic, despites the formation of a four-membered cyclically strained ring. The exothermic character of the electrocyclic reaction is due to the generation of an 
aromatic ring along the reaction. Entropy effects for the electrocyclic pathway are insignificant and this reaction is spontaneous at all studied temperatures. According to the thermodynamic data, synthesis of compound $\mathbf{3}$ from the pyrolysis of compound $\mathbf{1}$ at higher temperatures can take place with higher efficiency, which is in sharp agreement with the experimental observations. The temperature-dependent rate constants corrected by Eckart tunneling effect and their Arrhenius parameters for the cheletropic extrusion and electrocyclic reaction is listed in Table 6.

Table 6. The temperature-dependent rate constants corrected by Eckart tunneling effect and fitted Arrhenius parameters for the cheletropic extrusion and electrocyclic reaction by means of TST theory, calculated at the M06-2X/aug-cc-pVTZ level of theory

\begin{tabular}{cccccc}
\hline & $\kappa$ & $T(\mathrm{~K}) \pm 20 \%$ & $k\left(\mathrm{~s}^{-1}\right)$ & $A\left(\mathrm{~s}^{-1}\right)$ & $E_{\mathrm{a}}(\mathrm{kJ} / \mathrm{mol})$ \\
\hline \multirow{2}{*}{ Cheletropic } & 1.00 & 733 & $6.02 \times 10^{2}$ & $1.90 \times 10^{15}$ & 175.2 \\
extrusion & 1.02 & 833 & $1.94 \times 10^{4}$ & $1.94 \times 10^{15}$ & 175.4 \\
& 1.00 & 943 & $3.67 \times 10^{5}$ & $2.16 \times 10^{15}$ & 176.1 \\
& 1.02 & 1043 & $3.26 \times 10^{6}$ & $2.18 \times 10^{15}$ & 176.2 \\
Electrocyclic & 1.07 & 733 & $5.20 \times 10^{3}$ & $2.72 \times 10^{12}$ & 122.3 \\
reaction & 1.05 & 833 & $5.81 \times 10^{4}$ & $2.82 \times 10^{12}$ & 122.5 \\
& 1.04 & 943 & $4.58 \times 10^{5}$ & $2.89 \times 10^{12}$ & 122.7 \\
& 1043 & $2.06 \times 10^{6}$ & $2.96 \times 10^{12}$ & 122.8 \\
\hline
\end{tabular}

At all studied temperatures, tunneling effects are negligible and can be ignored. According to the obtained activation energy values the calculated barrier of cheletropic extrusion process is about $50 \mathrm{~kJ} / \mathrm{mol}$ higher than that for the electrocyclic reaction.

Further fall-off curve plots for the unimolecular rate constants $\left(k_{\text {uni }}\right)$ for the cheletropic extrusion and electrocyclic reaction as a function of pressure are displayed in Figure 3. In Tables 7 and 8 we also supply detailed values for the high pressure limit of rate constants $\left(k_{\infty}\right)$, atmospheric rate constant $\left(k^{1 \mathrm{~atm}}\right)$, low pressure limit of rate constants $\left(k_{0}\right)$, transition pressure $\left(P_{1 / 2}\right)$ values and their Lennard-Jones collision frequency $\left(\mathrm{Z}_{\mathrm{LJ}}\right)$ values for these reactions.

The RRKM equation modeling demonstrated that at atmospheric pressure and the lower pressures of the troposphere, the kinetic rates of cheletropic extrusion at 943 and $1043 \mathrm{~K}$ are in the fall-off regime. At these temperatures, pressures larger than $\sim 10$ atm are required for ensuring a saturation to the high pressure limit of the RRKM unimolecular rate constants. 
Consequently, transition state theory slightly breaks down at temperatures larger than $943 \mathrm{~K}$ and the fall-off expression is necessary for the kinetic modeling at atmospheric pressure.
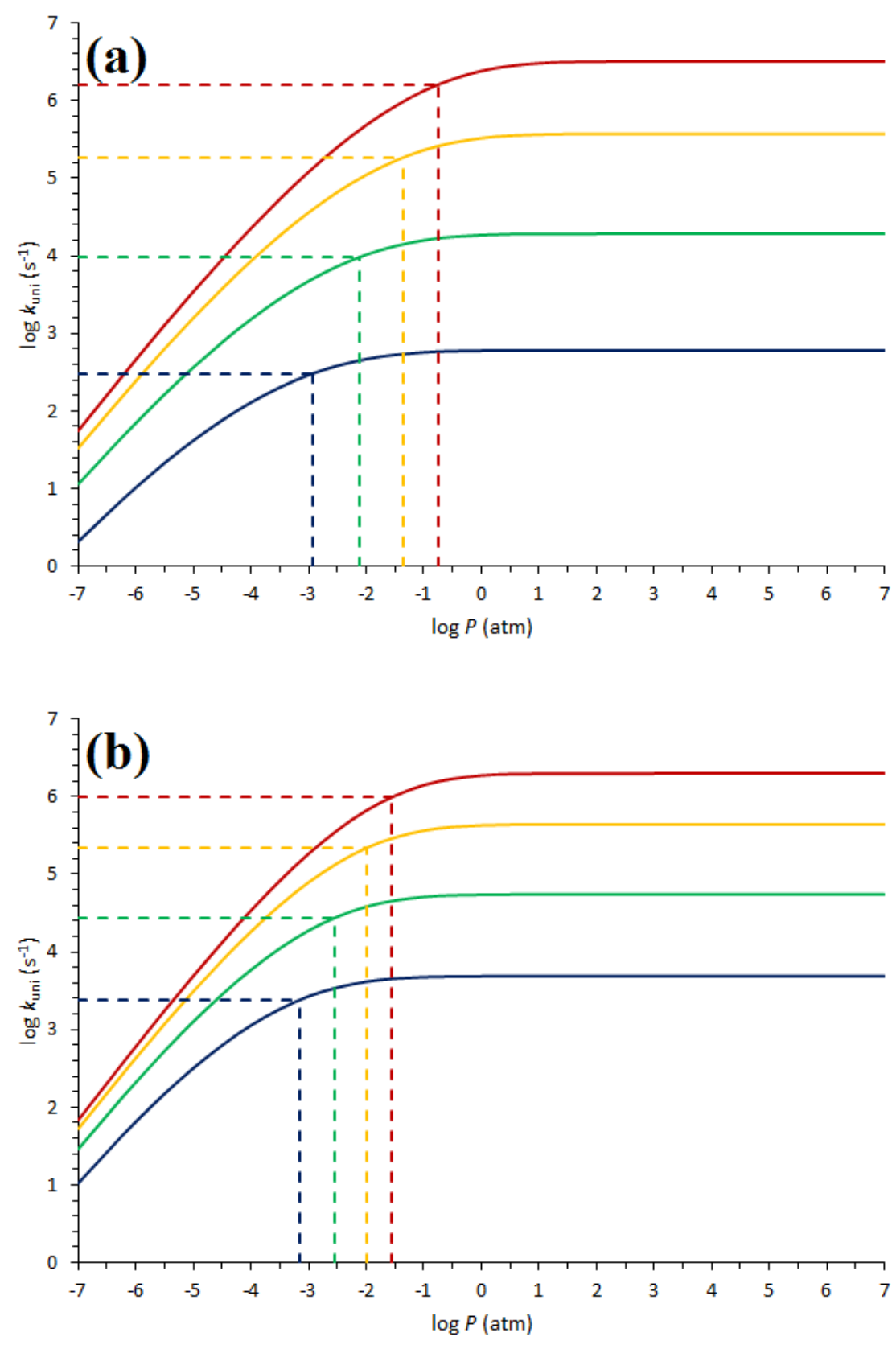

Figure 3. Fall-off plots for the rate constants as a function of pressure for the (a) cheletropic extrusion and (b) electrocyclic reaction at $733 \mathrm{~K}$ (blue line), $833 \mathrm{~K}$ (green line), $943 \mathrm{~K}$ (yellow line), and $1043 \mathrm{~K}$ (red line) by means of RRKM theory calculated at the M06-2X/aug-cc-pVTZ level of theory. Fall-off regions are separated by dashed lines. 
Table 7. High pressure rate constant $\left(k_{\infty}\right)$, atmospheric rate constant $\left(k^{1 \mathrm{~atm}}\right)$, low pressure rate constant $\left(k_{\mathrm{o}}\right)$, Lennard-Jones collision frequency $\left(\mathrm{Z}_{\mathrm{LJ}}\right)$, and transition pressure $\left(P_{1 / 2}\right)$ for the cheletropic extrusion by means of RRKM theory calculated at the M06-2X/aug-cc-pVTZ level of theory

\begin{tabular}{cccccc}
\hline$T(\mathrm{~K}) \pm 20 \%$ & $\begin{array}{c}k_{\infty} \\
\left(\mathrm{s}^{-1}\right)\end{array}$ & $\begin{array}{c}k^{\text {latm }} \\
\left(\mathrm{s}^{-1}\right)\end{array}$ & $\begin{array}{c}k_{\mathrm{o}} \\
\left(\mathrm{cm}^{3} \text { molecule }^{-1} \mathrm{~s}^{-1}\right)\end{array}$ & $\begin{array}{c}\mathrm{Z}_{\mathrm{LJ}} \\
\left(\mathrm{cm}^{3} \mathrm{molecule}^{-1} \mathrm{~s}^{-1}\right)\end{array}$ & $\begin{array}{c}P_{1 / 2} \\
(\text { Torr })\end{array}$ \\
\hline 733 & $6.05 \times 10^{2}$ & $5.99 \times 10^{2}$ & $1.02 \times 10^{-11}$ & $6.59 \times 10^{-10}$ & 0.8 \\
833 & $1.92 \times 10^{4}$ & $1.85 \times 10^{4}$ & $3.69 \times 10^{-11}$ & $6.80 \times 10^{-10}$ & 5.7 \\
943 & $3.72 \times 10^{5}$ & $3.28 \times 10^{5}$ & $7.91 \times 10^{-11}$ & $7.02 \times 10^{-10}$ & 33.7 \\
1043 & $3.21 \times 10^{6}$ & $2.41 \times 10^{6}$ & $1.13 \times 10^{-10}$ & $7.20 \times 10^{-10}$ & 133.1 \\
\hline
\end{tabular}

Table 8. High pressure rate constant $\left(k_{\infty}\right)$, atmospheric rate constant $\left(k^{1 \mathrm{~atm}}\right)$, low pressure rate constant $\left(k_{\mathrm{o}}\right)$, Lennard-Jones collision frequency $\left(\mathrm{Z}_{\mathrm{LJ}}\right)$, and transition pressure $\left(P_{1 / 2}\right)$ for the electrocyclic reaction by means of RRKM theory calculated at the M06-2X/aug-cc-pVTZ level of theory

\begin{tabular}{cccccc}
\hline$T(\mathrm{~K}) \pm 20 \%$ & $\begin{array}{c}k_{\infty} \\
\left(\mathrm{s}^{-1}\right)\end{array}$ & $\begin{array}{c}k^{\text {1atm }} \\
\left(\mathrm{s}^{-1}\right)\end{array}$ & $\begin{array}{c}k_{\mathrm{o}} \\
\left(\mathrm{cm}^{3} \text { molecule }^{-1} \mathrm{~s}^{-1}\right)\end{array}$ & $\begin{array}{c}\mathrm{Z}_{\mathrm{LJ}} \\
\left(\mathrm{cm}^{3} \text { molecule }^{-1} \mathrm{~s}^{-1}\right)\end{array}$ & $\begin{array}{c}P_{1 / 2} \\
(\text { Torr })\end{array}$ \\
\hline 733 & $4.86 \times 10^{3}$ & $4.85 \times 10^{3}$ & $1.56 \times 10^{-11}$ & $6.14 \times 10^{-10}$ & 0.5 \\
833 & $5.49 \times 10^{4}$ & $5.44 \times 10^{4}$ & $4.24 \times 10^{-11}$ & $6.33 \times 10^{-10}$ & 2.1 \\
943 & $4.38 \times 10^{5}$ & $4.26 \times 10^{5}$ & $7.85 \times 10^{-11}$ & $6.54 \times 10^{-10}$ & 7.7 \\
1043 & $1.98 \times 10^{6}$ & $1.86 \times 10^{6}$ & $1.06 \times 10^{-10}$ & $6.71 \times 10^{-10}$ & 21.2 \\
\hline
\end{tabular}

Over the temperature range of 733-1043 K, the rate coefficients for the cheletropic extrusion and electrocyclic reaction at $1 \mathrm{~atm}$ are fitted to the Arrhenius equation and can be finally expressed by the equations:

$$
k_{\text {Cheletropi }}^{\text {RRKM }}=1.01 \times 10^{15} \times \exp \left(-\frac{171.3 \mathrm{~kJ} / \mathrm{mol}}{\mathrm{R} T}\right) \mathrm{s}^{-1}
$$

and

$$
k_{\text {Electrocydic }}^{\text {RRKM }}=2.52 \times 10^{12} \times \exp \left(-\frac{122.2 \mathrm{~kJ} / \mathrm{mol}}{\mathrm{R} T}\right) \mathrm{s}^{-1}
$$

The RRKM calculations indicate that the transition pressures $\left(P_{1 / 2}\right)$ for the cheletropic extrusion and electrocyclic reaction are low and vary in the range of $0.5-133.1$ Torr. 


\subsection{BET study of cheletropic extrusion and electrocyclic reaction}

\subsubsection{Cheletropic extrusion pathway}

The BET study of the cheletropic extrusion indicates that this reaction along the intrinsic reaction coordinate can be topologically characterized by 7 differentiated SSDs. The reaction path of the cheletropic extrusion is calculated by means of the IRC method and presented in Figure 4 with marked domains. The population of the most relevant ELF valence basins for compound 1, points $\left(\mathrm{P}_{i} ; i=1-6\right)$ along the reaction coordinate between the $\mathrm{SSDs}$, compound 2 , and $\mathrm{SO}_{2}$ are compiled in Table 9. Lewis type representation of bonding changes in different steps on the IRC path, as revealed from BET are graphically represented in Figure 5.

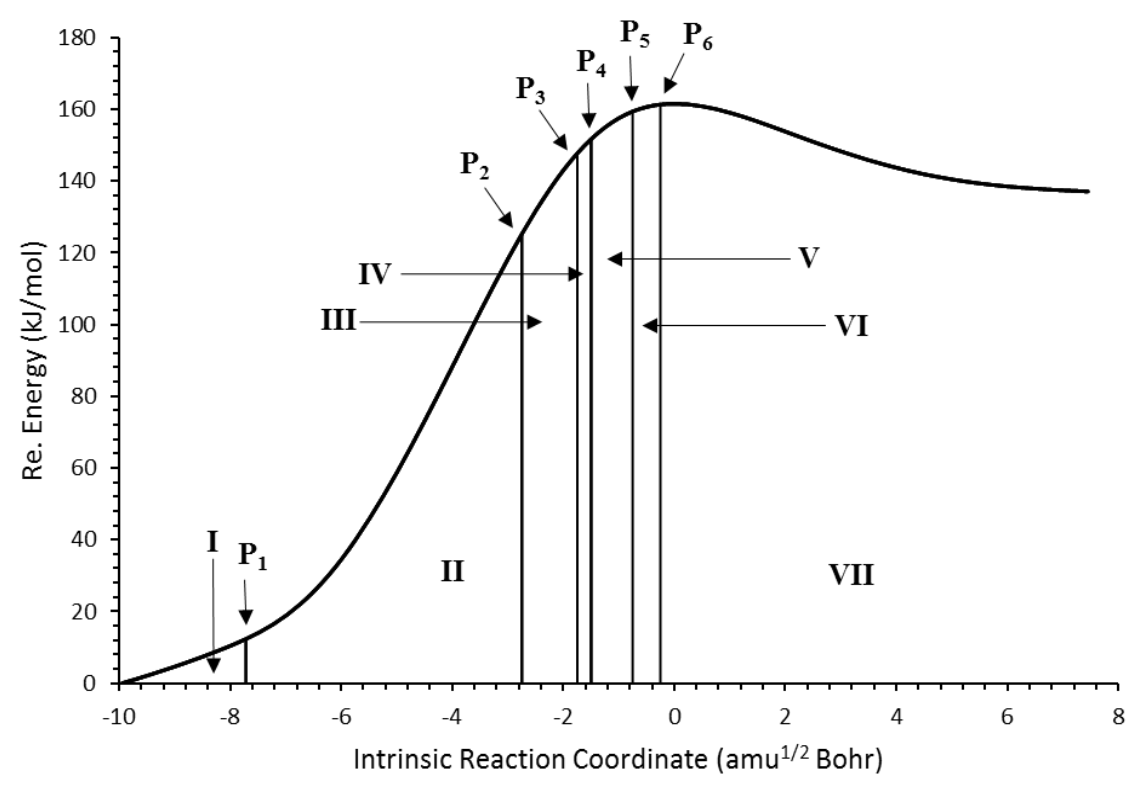

Figure 4. Schematic representation of the energy profile for the cheletropic extrusion calculated by means of the IRC method, with a step size of $0.1 \mathrm{amu}^{1 / 2}$ Bohr. The selected points of the IRC are considered for the ELF topological analysis. 
Table 9. Integrated electron populations for the valence ELF basins from the IRC points, defining 7 SSDs characterizing the molecular mechanism associated with the cheletropic extrusion calculated at the M06-2X/aug-cc-pVTZ level. The GEDT stands for global electron-density transfer $(\overline{\mathrm{e}})$

\begin{tabular}{|c|c|c|c|c|c|c|c|c|c|}
\hline & 1 & $\mathrm{P}_{1}$ & $\mathrm{P}_{2}$ & $\mathrm{P}_{3}$ & $\mathrm{P}_{4}$ & $\mathrm{P}_{5}$ & $\mathrm{P}_{6}$ & $\mathrm{TS}$ & $\mathbf{2}+\mathrm{SO}_{2}$ \\
\hline$d \mathrm{C}_{7}-\mathrm{S}(\AA)$ & 1.808 & 1.835 & 2.312 & 2.422 & 2.449 & 2.529 & 2.582 & 2.609 & - \\
\hline$d \mathrm{C}_{8}-\mathrm{S}(\AA)$ & 1.808 & 1.819 & 2.094 & 2.202 & 2.230 & 2.316 & 2.373 & 2.400 & - \\
\hline GEDT & -0.26 & -0.25 & -0.08 & -0.03 & -0.01 & 0.01 & 0.03 & 0.04 & - \\
\hline $\mathrm{V}\left(\mathrm{C}_{1}-\mathrm{C}_{2}\right)$ & 2.82 & 2.74 & 2.66 & 2.59 & 2.57 & 2.49 & 2.45 & 2.43 & 2.19 \\
\hline $\mathrm{V}\left(\mathrm{C}_{2}-\mathrm{C}_{3}\right)$ & 2.82 & 2.84 & 2.69 & 2.59 & 2.56 & 2.48 & 2.44 & 2.42 & 2.25 \\
\hline $\mathrm{V}\left(\mathrm{C}_{3}-\mathrm{C}_{4}\right)$ & 2.77 & 2.76 & 2.90 & 2.97 & 3.00 & 3.06 & 3.09 & 3.11 & 3.29 \\
\hline $\mathrm{V}\left(\mathrm{C}_{4}-\mathrm{C}_{5}\right)$ & 2.77 & 2.75 & 2.60 & 2.53 & 2.50 & 2.45 & 2.41 & 2.40 & 2.26 \\
\hline $\mathrm{V}\left(\mathrm{C}_{5}-\mathrm{C}_{6}\right)$ & 2.77 & 2.76 & 2.92 & 3.00 & 3.02 & 3.07 & 3.12 & 3.13 & 3.29 \\
\hline $\mathrm{V}\left(\mathrm{C}_{1}-\mathrm{C}_{6}\right)$ & 2.82 & 2.84 & 2.65 & 2.54 & 2.51 & 2.44 & 2.40 & 2.39 & 2.25 \\
\hline $\mathrm{V}\left(\mathrm{C}_{1}-\mathrm{C}_{7}\right)$ & 2.02 & 2.05 & 2.40 & 2.62 & 2.86 & 2.93 & 2.99 & 3.01 & 3.31 \\
\hline $\mathrm{V}\left(\mathrm{C}_{2}-\mathrm{C}_{8}\right)$ & 2.02 & 2.05 & 2.29 & 2.47 & 2.53 & 2.94 & 2.98 & 3.00 & 3.31 \\
\hline $\mathrm{V}\left(\mathrm{C}_{7}-\mathrm{S}\right)$ & 1.98 & 1.93 & - & - & - & - & - & - & - \\
\hline $\mathrm{V}\left(\mathrm{C}_{8}-\mathrm{S}\right)$ & 1.98 & 1.94 & 1.72 & - & - & - & - & - & - \\
\hline $\mathrm{V}\left(\mathrm{S}-\mathrm{O}_{1}\right)$ & 1.77 & 1.78 & 1.73 & 1.75 & 1.76 & 1.79 & 1.82 & 1.83 & 1.92 \\
\hline $\mathrm{V}\left(\mathrm{S}-\mathrm{O}_{2}\right)$ & 1.77 & 1.80 & 1.72 & 1.77 & 1.77 & 1.80 & 1.83 & 1.84 & 1.93 \\
\hline $\mathrm{V}\left(\mathrm{O}_{1}\right)$ & 2.55 & 3.40 & 2.97 & 2.98 & 2.98 & 2.98 & 2.97 & 2.96 & 2.84 \\
\hline $\mathrm{V}^{\prime}\left(\mathrm{O}_{1}\right)$ & 2.47 & 2.59 & 2.96 & 2.89 & 2.88 & 2.84 & 2.80 & 2.79 & 2.71 \\
\hline $\mathrm{V}^{\prime \prime}\left(\mathrm{O}_{1}\right)$ & 1.01 & - & - & - & - & - & - & - & - \\
\hline $\mathrm{V}\left(\mathrm{O}_{2}\right)$ & 2.08 & 3.43 & 3.00 & 2.99 & 2.99 & 2.97 & 2.97 & 2.97 & 2.84 \\
\hline $\mathrm{V}^{\prime}\left(\mathrm{O}_{2}\right)$ & 2.03 & 2.54 & 2.91 & 2.85 & 2.83 & 2.79 & 2.77 & 2.76 & 2.71 \\
\hline $\mathrm{V}^{\prime \prime}\left(\mathrm{O}_{2}\right)$ & 1.88 & - & - & - & - & - & - & - & - \\
\hline $\mathrm{V}(\mathrm{S})$ & - & - & 1.48 & 1.55 & 1.58 & 1.70 & 2.73 & 2.73 & 2.75 \\
\hline $\mathrm{V}^{\prime}(\mathrm{S})$ & - & - & - & 1.18 & 1.15 & 1.03 & - & - & - \\
\hline $\mathrm{V}\left(\mathrm{C}_{7}\right)$ & - & - & 0.33 & 0.21 & - & - & - & - & - \\
\hline $\mathrm{V}\left(\mathrm{C}_{8}\right)$ & - & - & - & 0.38 & 0.35 & - & - & - & - \\
\hline
\end{tabular}



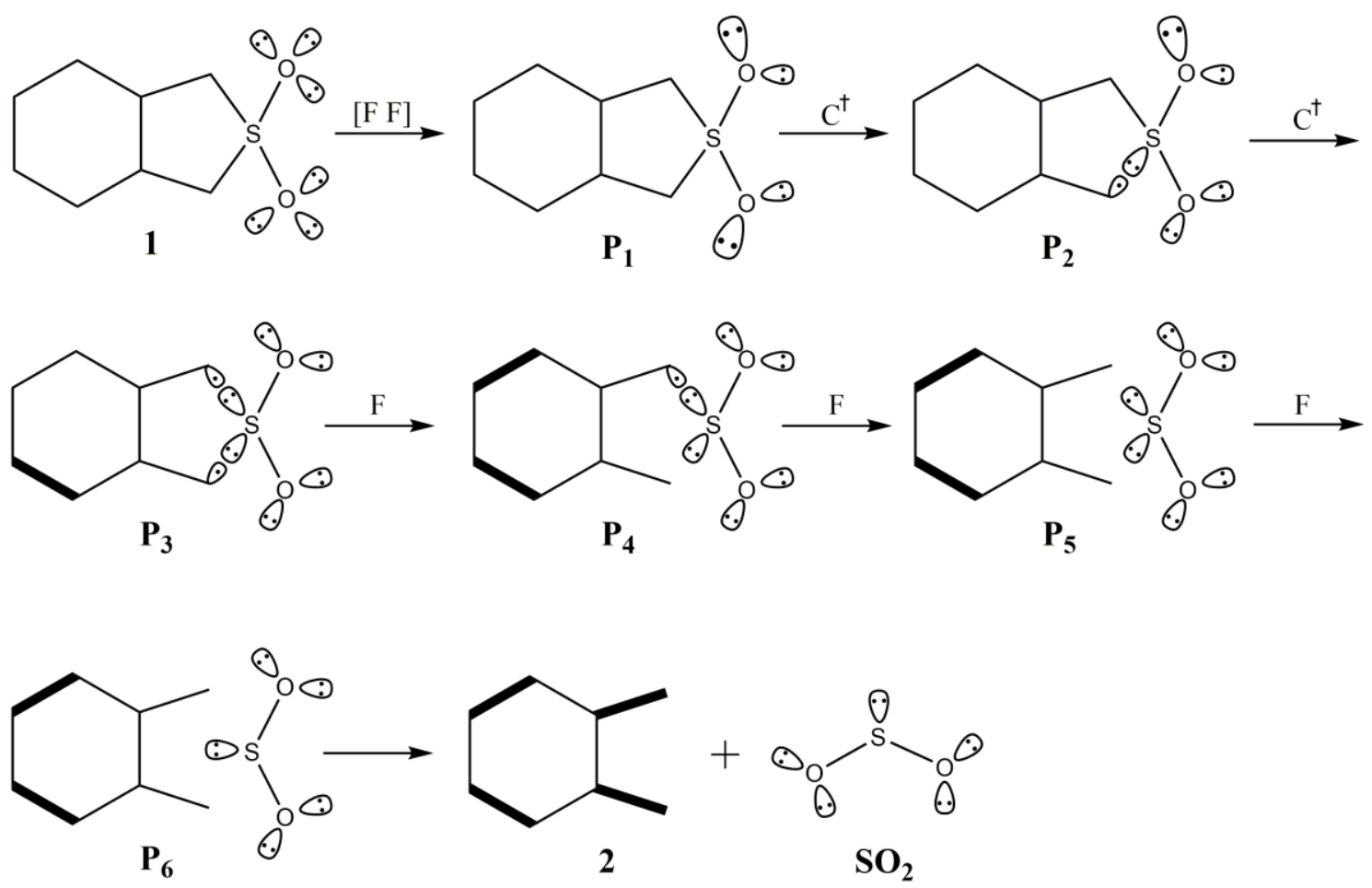

Figure 5. Lewis type representation of bonding changes based on the ELF topology along the reaction coordinate of cheletropic extrusion. Filled lines, and large ellipses with two dots indicate respectively disynaptic and lone electron pairs monosynaptic basins with a population larger than 3.0 è. Small ellipses with one dots indicate non-bonding electron density with a population smaller than $1.0 \overline{\mathrm{e}}$.

The SSD I, $1.808 \leq d \mathrm{C}_{7}-\mathrm{S}(\AA)<1.835$ and $1.808 \leq d \mathrm{C}_{8}-\mathrm{S}(\AA)<1.819$, begins at compound $\mathbf{1}$ and ends before $\mathbf{P}_{1}$ point. At compound $\mathbf{1}, d \mathrm{C}_{7}-\mathrm{S}=d \mathrm{C}_{8}-\mathrm{S}=1.808 \AA$, a significant GEDT equal to $-0.26 \overline{\mathrm{e}}$ takes place from $\mathrm{SO}_{2}$ to the diene fragment. Negative value of GEDT is as the consequence of a back donation process. The ELF picture of compound $\mathbf{1}$ reveals three disynaptic basins $\mathrm{V}\left(\mathrm{C}_{1}-\mathrm{C}_{2}\right), \mathrm{V}\left(\mathrm{C}_{2}-\mathrm{C}_{3}\right)$, and $\mathrm{V}\left(\mathrm{C}_{1}-\mathrm{C}_{6}\right)$ associated with the $\mathrm{C}_{1}-\mathrm{C}_{2}, \mathrm{C}_{2}-\mathrm{C}_{3}$, and $\mathrm{C}_{1}-\mathrm{C}_{6}$ bonding regions, integrating to $2.82 \mathrm{e}$; three disynaptic basins $\mathrm{V}\left(\mathrm{C}_{3}-\mathrm{C}_{4}\right), \mathrm{V}\left(\mathrm{C}_{4}-\mathrm{C}_{5}\right)$, and $\mathrm{V}\left(\mathrm{C}_{5}-\mathrm{C}_{6}\right)$ associated with the $\mathrm{C}_{3}-\mathrm{C}_{4}, \mathrm{C}_{4}-\mathrm{C}_{5}$, and $\mathrm{C}_{5}-\mathrm{C}_{6}$ bonds, integrating to $2.77 \mathrm{e}$; two disynaptic basins $\mathrm{V}\left(\mathrm{C}_{1}-\mathrm{C}_{7}\right)$ and $\mathrm{V}\left(\mathrm{C}_{2}-\mathrm{C}_{8}\right)$ associated with the $\mathrm{C}_{1}-\mathrm{C}_{7}$ and $\mathrm{C}_{2}-\mathrm{C}_{8}$ bonds, integrating to $2.02 \overline{\mathrm{e}}$; two disynaptic basins $\mathrm{V}\left(\mathrm{C}_{7}-\mathrm{S}\right)$ and $\mathrm{V}\left(\mathrm{C}_{8}-\mathrm{S}\right)$ associated with the $\mathrm{C}_{7}-\mathrm{S}$ and $\mathrm{C}_{8}-\mathrm{S}$ bonds, integrating to $1.98 \mathrm{e}$; and two disynaptic basins $\mathrm{V}\left(\mathrm{S}-\mathrm{O}_{1}\right)$ and $\mathrm{V}\left(\mathrm{S}-\mathrm{O}_{2}\right)$ associated with the $\mathrm{S}-\mathrm{O}_{1}$ and $\mathrm{S}-\mathrm{O}_{2}$ bonds, integrating to $1.77 \overline{\mathrm{e}}$. Also, compound $\mathbf{1}$ shows three 
monosynaptic basins $\mathrm{V}\left(\mathrm{O}_{1}\right), \mathrm{V}^{\prime}\left(\mathrm{O}_{1}\right)$, and $\mathrm{V}^{\prime \prime}\left(\mathrm{O}_{1}\right)$ integrating to $2.55 \overline{\mathrm{e}}, 2.47 \overline{\mathrm{e}}$, and $1.01 \overline{\mathrm{e}}$, respectively; and three monosynaptic basins $\mathrm{V}\left(\mathrm{O}_{2}\right), \mathrm{V}^{\prime}\left(\mathrm{O}_{2}\right)$, and $\mathrm{V}^{\prime \prime}\left(\mathrm{O}_{2}\right)$ integrating to $2.08 \overline{\mathrm{e}}$, $2.03 \overline{\mathrm{e}}$, and $1.88 \overline{\mathrm{e}}$, respectively which are associated with the lone pairs located on the $\mathrm{O}_{1}$ and $\mathrm{O}_{2}$ oxygen atoms. High population of oxygen lone pairs together with the low population of S-O bonds indicate that two $\mathrm{S}-\mathrm{O}$ bonds of $\mathrm{SO}_{2}$ fragment are highly polarized. The increment of total electronic energy to reach $\mathbf{P}_{1}$ point is $12.34 \mathrm{~kJ} / \mathrm{mol}$ with respect to the compound $\mathbf{1}$.

The SSD II, $1.835 \leq d \mathrm{C}_{7}-\mathrm{S}(\AA)<2.312$ and $1.819 \leq d \mathrm{C}_{8}-\mathrm{S}(\AA)<2.094$, begins from $\mathbf{P}_{1}$ point and ends before $\mathbf{P}_{2}$ point. The most significant topological change is merging of $\mathrm{V}^{\prime \prime}\left(\mathrm{O}_{1}\right)$ and $\mathrm{V}^{\prime \prime}$ $\left(\mathrm{O}_{2}\right)$ monosynaptic basins into $\mathrm{V}\left(\mathrm{O}_{1}\right)$ and $\mathrm{V}^{\prime}\left(\mathrm{O}_{1}\right)$, and $\mathrm{V}\left(\mathrm{O}_{2}\right)$ and $\mathrm{V}^{\prime}\left(\mathrm{O}_{2}\right)$ monosynaptic basins, integrating $3.40 \overline{\mathrm{e}}$ and $2.59 \overline{\mathrm{e}}$, and $3.43 \overline{\mathrm{e}}$ and $2.54 \overline{\mathrm{e}}$. These changes correspond to two concurrent fold $[\mathrm{FF}]$ catastrophes. At P1 point the GEDT decreases to $-0.25 \overline{\mathrm{e}}$. The SSD II is the most costly in terms of total electronic energy with an increment of $112.95 \mathrm{~kJ} / \mathrm{mol}$ with respect to the $\mathbf{P}_{1}$ point to reach the breaking of single $\mathrm{C}_{7}-\mathrm{S}$ bond.

The SSD III, $2.312 \leq d \mathrm{C}_{7}-\mathrm{S}(\AA)<2.422$ and $2.094 \leq d \mathrm{C}_{8}-\mathrm{S}(\AA)<2.202$, begins at $\mathbf{P}_{2}$ point and ends before $\mathbf{P}_{\mathbf{3}}$ point. The most notable topological changes are disappearing of disynaptic basin $\mathrm{V}\left(\mathrm{C}_{7}-\mathrm{S}\right)$ which is associated with the single $\mathrm{C}_{7}-\mathrm{S}$ bond and appearing of two new monosynaptic basins $\mathrm{V}(\mathrm{S})$ and $\mathrm{V}\left(\mathrm{C}_{7}\right)$ which are associated with the lone pair located on the $\mathrm{S}$ atom and the pseudoradical center on the $\mathrm{C}_{7}$ atom, integrating to $1.48 \overline{\mathrm{e}}$ and $0.33 \overline{\mathrm{e}}$, respectively. These changes belong to the cusp $\mathrm{C}^{\dagger}$ catastrophe. At $\mathbf{P}_{2}$ point the GEDT decreases to $-0.08 \overline{\mathrm{e}}$ and increment of the total electronic energy of the system, in the third SSD, to reach the breaking of covalent $\mathrm{C}_{8}-\mathrm{S}$ bond is $22.45 \mathrm{~kJ} / \mathrm{mol}$.

The SSD IV, $2.422 \leq d \mathrm{C}_{7}-\mathrm{S}(\AA)<2.449$ and $2.202 \leq d \mathrm{C}_{8}-\mathrm{S}(\AA)<2.230$, begins at $\mathbf{P}_{3}$ point and ends before $\mathbf{P}_{4}$ point. In this domain, the disynaptic basin $\mathrm{V}\left(\mathrm{C}_{8}-\mathrm{S}\right)$ which is associated with the covalent $\mathrm{C}_{8}-\mathrm{S}$ bond has disappeared and two new monosynaptic basins $\mathrm{V}^{\prime}(\mathrm{S})$ and $\mathrm{V}\left(\mathrm{C}_{8}\right)$ have appeared which are associated with the second lone pair located on the $\mathrm{S}$ atom and the pseudoradical center on the $\mathrm{C}_{8}$ atom, whose electronic population integrates to $1.18 \overline{\mathrm{e}}$ and $0.38 \overline{\mathrm{e}}$, respectively. Along the fourth ELF SSD there is a charge transfer from the $\mathrm{V}^{\prime}(\mathrm{S})$ basin to the $\mathrm{V}$ (S) ones which is the starting point of merging of these monosynaptics. Comparison of SSDs reveals that the fourth SSD is the shortest phase with increment of $3.98 \mathrm{~kJ} / \mathrm{mol}$ in total electronic 
energy and can be introduced by a cusp $\mathrm{C}^{\dagger}$ catastrophe. At $\mathbf{P}_{3}$ point, a GEDT $-0.03 \overline{\mathrm{e}}$ is observed from the diene fragment to $\mathrm{SO}_{2}$.

The SSD V, $2.449 \leq d \mathrm{C}_{7}-\mathrm{S}(\AA)<2.529$ and $2.230 \leq d \mathrm{C}_{8}-\mathrm{S}(\AA)<2.316$, and SSD VI, $2.529 \leq d$ $\mathrm{C}_{7}-\mathrm{S}(\AA)<2.582$ and $2.316 \leq d \mathrm{C}_{8}-\mathrm{S}(\AA)<2.373$, start at $\mathbf{P}_{4}$ and $\mathbf{P}_{5}$ points with the disappearance of the monosynaptic basins $\mathrm{V}\left(\mathrm{C}_{7}\right)$ and $\mathrm{V}\left(\mathrm{C}_{8}\right)$, respectively, which can be expressed by two successive fold F catastrophes. The GEDT at $\mathbf{P}_{4}$ and $\mathbf{P}_{5}$ points are equal to $0.01 \overline{\mathrm{e}}$ and $0.01 \overline{\mathrm{e}}$, respectively.

The extremely long phase SSD VII, $2.582 \leq d \mathrm{C}_{7}-\mathrm{S}(\AA)$ and $2.373 \leq d \mathrm{C}_{8}-\mathrm{S}(\AA)$, begins from $\mathbf{P}_{6}$ point and connects to the separated compound $\mathbf{2}$ and sulfur dioxide. At $\mathbf{P}_{6}$ point, the monosynaptic basin $\mathrm{V}^{\prime}(\mathrm{S})$ has merged into $\mathrm{V}(\mathrm{S})$ which are associated with the sulfur lone pairs by a fold $\mathrm{F}$ catastrophe. At P6 point, the observed GEDT value is 0.03 è. Upon using the notations by Polo et al. [20], the cheletropic extrusion reaction can thus be characterized by 7 SSDs associated to the sequence of catastrophes $\mathrm{C}_{8} \mathrm{H}_{8} \mathrm{SO}_{2}$ : 7-[F F]C $\mathrm{C}^{\dagger} \mathrm{FFF}-0: \mathrm{C}_{8} \mathrm{H}_{8}+\mathrm{SO}_{2}$.

The retarded transition state TS1 associated with the cheletropic extrusion is located at SSD VII. Basins in the transition state are discriminated by the reduction of reducible domains. The bifurcation graph of ELF localization domains with respect to the ELF critical values shows the hierarchy of ELF basin domains of transition state TS1 (see Figure 6).

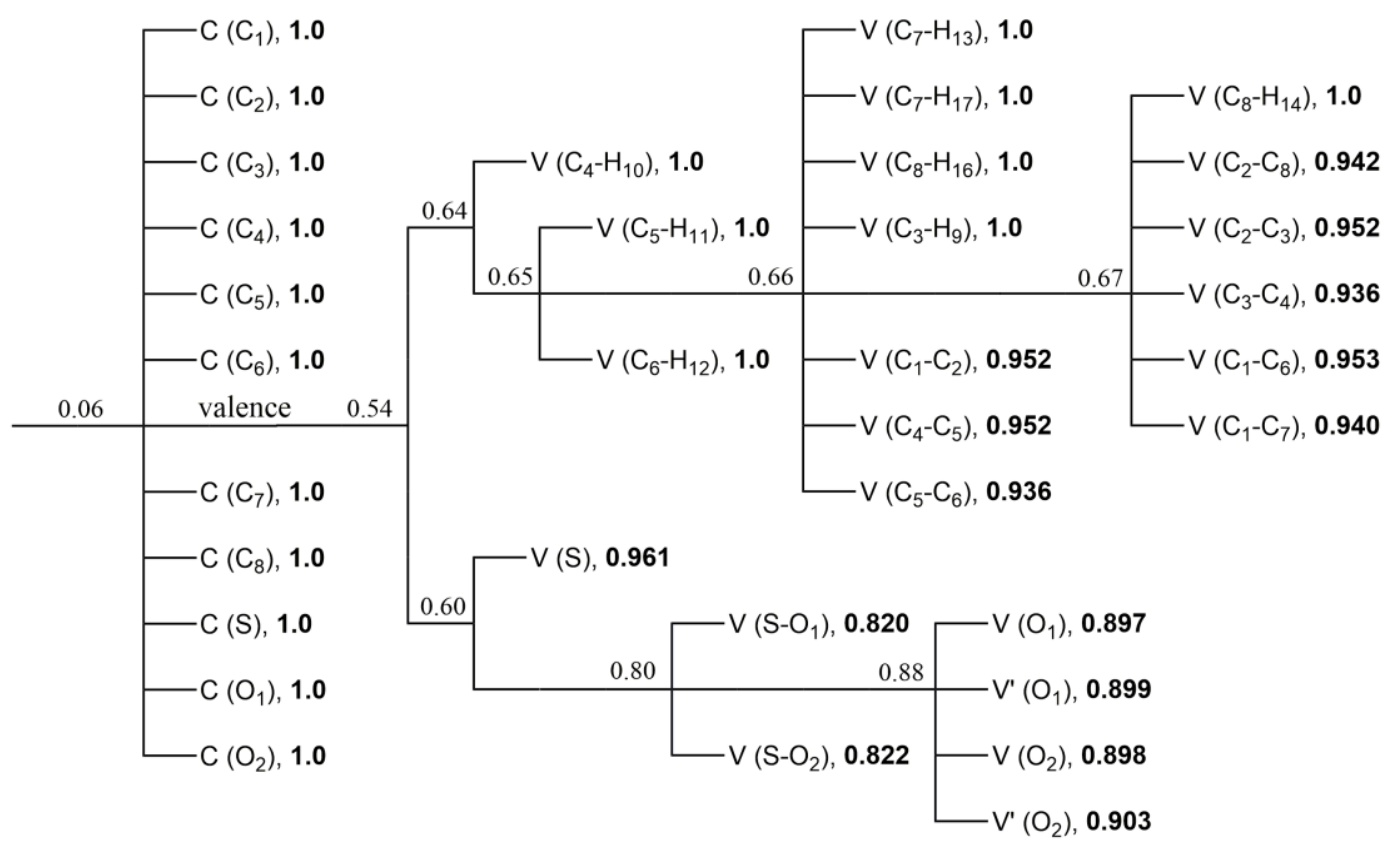

Figure 6. Reduction tree diagrams of ELF localization domains for the transition state belonging to the cheletropic extrusion process. 
ELF basin domains of TS1 can be divided to eleven core attractors, eight protonated disynaptic attractors, ten disynaptic attractors, and five monosynaptic attractors. The first separation of ELF localization domains into core and valence basins occurs at low ELF value $\eta(\mathbf{r})=0.06$. After core-valence separation, the valence domain undergoes second separation into diene $(i)$ and sulfur dioxide (ii) fragments at ELF value $\eta(\mathbf{r})=0.54$.

(i) The valence basin of diene fragment is split into a protonated disynaptic attractor $\mathrm{V}\left(\mathrm{C}_{4}-\mathrm{H}_{10}\right)$ at ELF value $\eta(\mathbf{r})=0.64$, and immediately followed at ELF value $\eta(\mathbf{r})=0.65$ by detachment of two protonated disynaptic attractors $\mathrm{V}\left(\mathrm{C}_{5}-\mathrm{H}_{11}\right)$ and $\mathrm{V}\left(\mathrm{C}_{6}-\mathrm{H}_{12}\right)$. The remained domain of diene fragment is reduced at ELF value $\eta(\mathbf{r})=0.66$ into four protonated disynaptic attractors $\mathrm{V}$ $\left(\mathrm{C}_{7}-\mathrm{H}_{13}\right), \mathrm{V}\left(\mathrm{C}_{7}-\mathrm{H}_{17}\right), \mathrm{V}\left(\mathrm{C}_{8}-\mathrm{H}_{16}\right)$, and $\mathrm{V}\left(\mathrm{C}_{3}-\mathrm{H}_{9}\right)$; and three disynaptic attractors $\mathrm{V}\left(\mathrm{C}_{1}-\mathrm{C}_{2}\right), \mathrm{V}$ $\left(\mathrm{C}_{4}-\mathrm{C}_{5}\right)$, and $\mathrm{V}\left(\mathrm{C}_{5}-\mathrm{C}_{6}\right)$. Finally, at ELF value $\eta(\mathbf{r})=0.67$ the residual domain of diene fragment is reduced into a protonated disynaptic attractor $\mathrm{V}\left(\mathrm{C}_{8}-\mathrm{H}_{14}\right)$ and five disynaptic attractors $\mathrm{V}$ $\left(\mathrm{C}_{2}-\mathrm{C}_{8}\right), \mathrm{V}\left(\mathrm{C}_{2}-\mathrm{C}_{3}\right), \mathrm{V}\left(\mathrm{C}_{3}-\mathrm{C}_{4}\right), \mathrm{V}\left(\mathrm{C}_{1}-\mathrm{C}_{6}\right)$, and $\mathrm{V}\left(\mathrm{C}_{1}-\mathrm{C}_{7}\right)$.

(ii) The sulfur dioxide domain is reduced at ELF value $\eta(\mathbf{r})=0.60$ into a monosynaptic attractor $\mathrm{V}(\mathrm{S})$, and followed at ELF value $\eta(\mathbf{r})=0.80$ by detachment of two disynaptic attractors $\mathrm{V}$ $\left(\mathrm{S}-\mathrm{O}_{1}\right)$ and $\mathrm{V}\left(\mathrm{S}-\mathrm{O}_{2}\right)$. Finally, four monosynaptic attractors $\mathrm{V}\left(\mathrm{O}_{1}\right), \mathrm{V}^{\prime}\left(\mathrm{O}_{1}\right), \mathrm{V}\left(\mathrm{O}_{2}\right)$, and $\mathrm{V}^{\prime}\left(\mathrm{O}_{2}\right)$ are separated at ELF value $\eta(\mathbf{r})=0.88$.

Color-filled maps of the electron localization function in the molecular plane defined by plane of the $\mathrm{C}_{7}-\mathrm{S}-\mathrm{C}_{8}$ for compound $\mathbf{1}$, TS1, and points $\left(\mathrm{P}_{\mathrm{i}} ; \mathrm{i}=1-6\right)$ along the reaction coordinate between the SSDs that topologically characterize the molecular mechanism are presented in Figure 7. It is very clear that the breaking of $\left(\mathrm{C}_{7}-\mathrm{S}\right)$ and $\left(\mathrm{C}_{8}-\mathrm{S}\right)$ bonds occurs at $\mathbf{P}_{2}$ and $\mathbf{P}_{3}$ points, respectively. During the reaction, ELF value between $\mathrm{C}$ and $\mathrm{S}$ atoms decreases continuously to approach to zero value at the end of the process. 

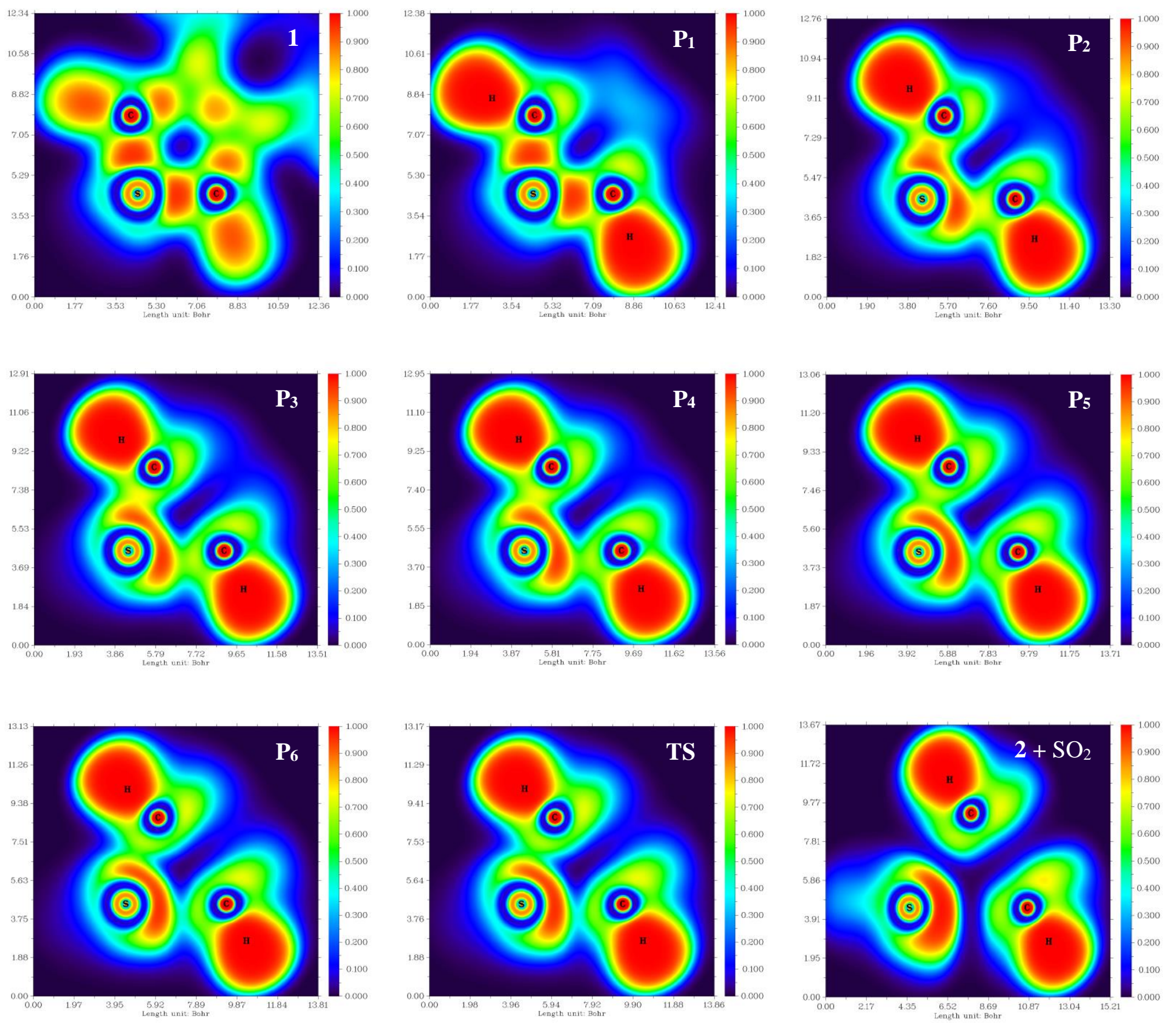

Figure 7. Color-filled maps of the electron localization function in the molecular plane defined by plane of the $\mathrm{C}_{7}-\mathrm{S}-\mathrm{C}_{8}$ for reactant, TS, selected points separating the SSDs along the reaction coordinate, and a point at end of cheletropic extrusion process. The ELF values [0 to 1] are mapped on a blue-green-red color scale indicated on the right of each representation. Blue and red colors indicate respectively no electron and high electron localization. 


\subsubsection{Electrocyclic reaction pathway}

The BET study of the electrocyclic reaction shows that this reaction along the reaction path can be topologically characterized by three differentiated SSDs. The energy profile for the electrocyclic reaction calculated by means of the IRC method is presented in Figure 8 with three differentiated separated domains. The ELF valence basin populations for compound 2, critical points $\mathbf{P}_{1}$ and $\mathbf{P}_{2}$ along the reaction coordinate between the SSDs, and compound $\mathbf{3}$ are tabulated in Table 10. Lewis type representation of bonding changes in different steps on the IRC path, as revealed from BET are graphically sketched in Figure 9.

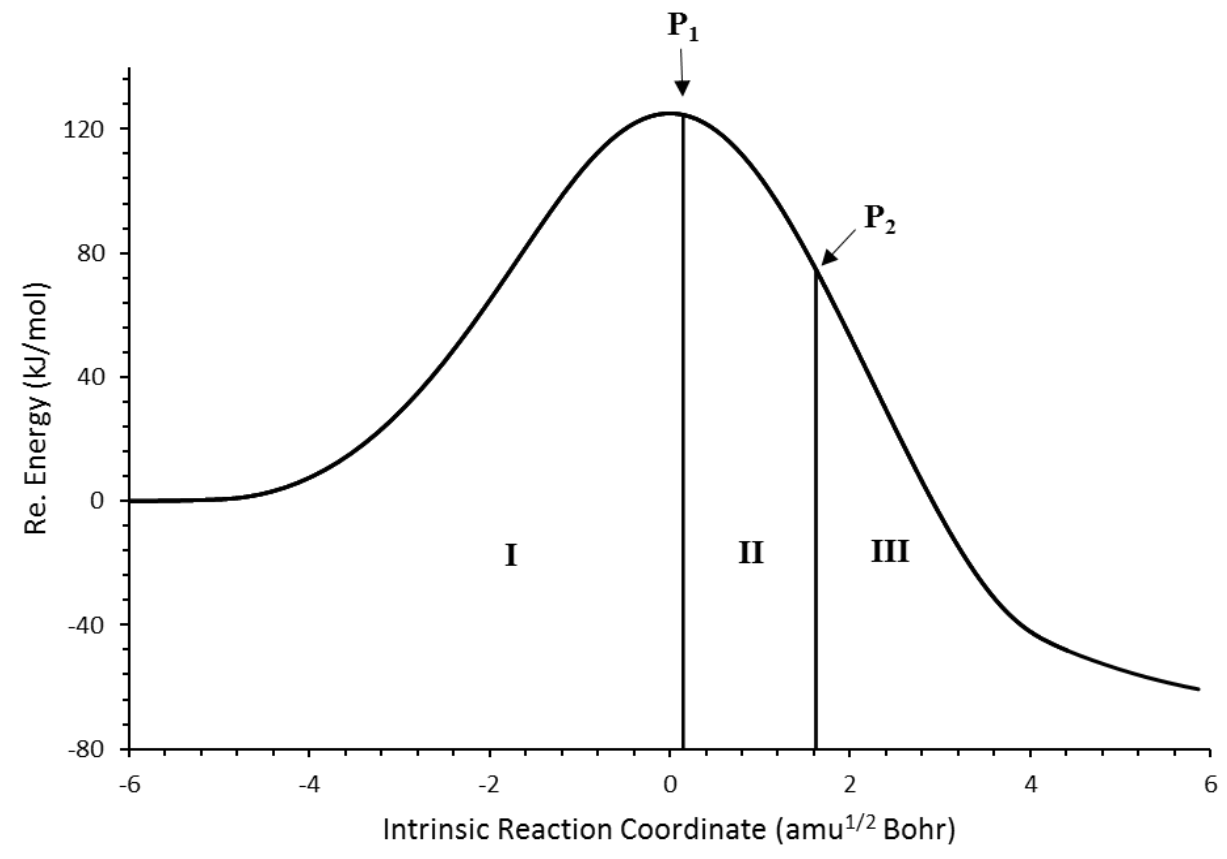

Figure 8. Schematic representation of the energy profile for the electrocyclic reaction calculated by means of the IRC method, with a step size of $0.1 \mathrm{amu}^{1 / 2}$ Bohr. The selected points of the IRC are considered for the ELF topological analysis. 
Table 10. Integrated electron populations for the valence ELF basins from the IRC points, defining 3 SSDs characterizing the molecular mechanism associated with the electrocyclic reaction calculated at the M06-2X/aug-cc-pVTZ level of theory

\begin{tabular}{lccccc}
\hline & $\mathbf{2}$ & $\mathrm{TS}$ & $\mathrm{P}_{1}$ & $\mathrm{P}_{2}$ & $\mathbf{3}$ \\
\hline$d \mathrm{C}_{7}-\mathrm{C}_{8}(\AA)$ & 2.979 & 2.269 & 2.248 & 2.018 & 1.570 \\
$\mathrm{~V}\left(\mathrm{C}_{1}-\mathrm{C}_{2}\right)$ & 2.19 & 2.51 & 2.53 & 2.61 & 2.70 \\
$\mathrm{~V}\left(\mathrm{C}_{2}-\mathrm{C}_{3}\right)$ & 2.25 & 2.58 & 2.61 & 2.84 & 2.87 \\
$\mathrm{~V}\left(\mathrm{C}_{3}-\mathrm{C}_{4}\right)$ & 3.29 & 3.02 & 3.00 & 2.79 & 2.75 \\
$\mathrm{~V}\left(\mathrm{C}_{4}-\mathrm{C}_{5}\right)$ & 2.26 & 2.54 & 2.57 & 2.75 & 2.80 \\
$\mathrm{~V}\left(\mathrm{C}_{5}-\mathrm{C}_{6}\right)$ & 3.29 & 3.02 & 3.00 & 2.79 & 2.75 \\
$\mathrm{~V}\left(\mathrm{C}_{1}-\mathrm{C}_{6}\right)$ & 2.25 & 2.58 & 2.61 & 2.84 & 2.87 \\
$\mathrm{~V}\left(\mathrm{C}_{1}-\mathrm{C}_{7}\right)$ & 3.31 & 2.66 & 2.57 & 2.19 & 2.01 \\
$\mathrm{~V}\left(\mathrm{C}_{2}-\mathrm{C}_{8}\right)$ & 3.31 & 2.66 & 2.57 & 2.19 & 2.01 \\
$\mathrm{~V}\left(\mathrm{C}_{7}-\mathrm{C}_{8}\right)$ & - & - & - & 1.24 & 1.81 \\
$\mathrm{~V}\left(\mathrm{C}_{7}\right)$ & - & - & 0.23 & - & - \\
$\mathrm{V}\left(\mathrm{C}_{8}\right)$ & - & - & 0.23 & - & - \\
\hline
\end{tabular}

The SSD I, $2.248<d \mathrm{C}_{7}-\mathrm{C}_{8}(\AA) \leq 2.979$, begins from compound $\mathbf{2}$ and ends before $\mathbf{P}_{1}$ point. The ELF analysis of compound 2 exhibits two disynaptic basins $\mathrm{V}\left(\mathrm{C}_{1}-\mathrm{C}_{2}\right)$ and $\mathrm{V}\left(\mathrm{C}_{4}-\mathrm{C}_{5}\right)$ corresponding to single $\mathrm{C}_{1}-\mathrm{C}_{2}$ and $\mathrm{C}_{4}-\mathrm{C}_{5}$ bonds, whose electronic populations integrate to $2.19 \overline{\mathrm{e}}$ and $2.26 \overline{\mathrm{e}}$, respectively. In addition, the ELF topology of compound $\mathbf{2}$ also shows the presence of two disynaptic basins $\mathrm{V}\left(\mathrm{C}_{2}-\mathrm{C}_{3}\right)$ and $\mathrm{V}\left(\mathrm{C}_{1}-\mathrm{C}_{6}\right)$ associated with the single $\mathrm{C}_{2}-\mathrm{C}_{3}$ and $\mathrm{C}_{1}-\mathrm{C}_{6}$ bonds, which integrate to $2.25 \mathrm{e}$; two disynaptic basins $\mathrm{V}\left(\mathrm{C}_{3}-\mathrm{C}_{4}\right)$ and $\mathrm{V}\left(\mathrm{C}_{5}-\mathrm{C}_{6}\right)$ belonging to the $\mathrm{C}_{3}=\mathrm{C}_{4}$ and $\mathrm{C}_{5}=\mathrm{C}_{6}$ double bonds with populations of $3.29 \overline{\mathrm{e}}$; and two disynaptic basins $\mathrm{V}$ $\left(\mathrm{C}_{1}-\mathrm{C}_{7}\right)$ and $\mathrm{V}\left(\mathrm{C}_{2}-\mathrm{C}_{8}\right)$ corresponding to the $\mathrm{C}_{1}=\mathrm{C}_{7}$ and $\mathrm{C}_{2}=\mathrm{C}_{8}$ double bonds, whose electronic populations integrate to $3.31 \overline{\mathrm{e}}$. The SSD I is extremely long phase in which an advanced transition state associated with the electrocyclic reaction is located at it. Also, the SSD I is the most costly step in terms of total electronic energy with an increment of $121.62 \mathrm{~kJ} / \mathrm{mol}$ with respect to compound $\mathbf{2}$ which is required to allow the formation of pseudoradical centers.

The SSD II, $2.018<d \mathrm{C}_{7}-\mathrm{C}_{8}(\AA) \leq 2.248$, starts at $\mathbf{P}_{1}$ point and ends before $\mathbf{P}_{2}$ point. The most significant topological changes imply depopulation of disynaptic basins $\mathrm{V}\left(\mathrm{C}_{1}-\mathrm{C}_{7}\right)$ and $\mathrm{V}$ $\left(\mathrm{C}_{2}-\mathrm{C}_{8}\right)$; and appearance of two low-populated monosynaptic basins $\mathrm{V}\left(\mathrm{C}_{7}\right)$ and $\mathrm{V}\left(\mathrm{C}_{8}\right)$, 
integrating each to $0.23 \overline{\mathrm{e}}$. These pseudoradical centers are responsible for the subsequent $\mathrm{C}_{7}-\mathrm{C}_{8}$ bond formation and their populations increase along the SSD II. Formation of pseudoradical centers belongs to two concurrent fold $\left[\mathrm{F}^{\dagger} \mathrm{F}^{\dagger}\right]$ catastrophes.

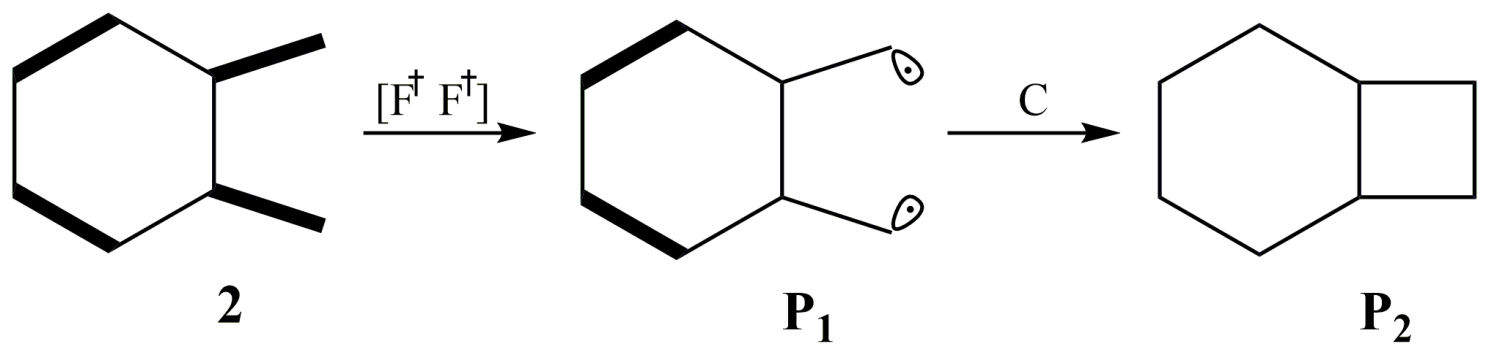

Figure 9. Lewis type representation of bonding changes based on the ELF topology along the electrocyclic reaction coordinate. Filled lines indicate disynaptic basins with a population larger than 3.0 e . Ellipses with one dots indicate non-bonding electron density with a population smaller than $1.0 \overline{\mathrm{e}}$.

The SSD III, $d \mathrm{C}_{7}-\mathrm{C}_{8}(\AA) \leq 2.018$, starts at $\mathbf{P}_{2}$ point and is continued until formation of the compound 3. C- to C- coupling between the pseudoradical centers generated in the previous SSD leads to the merging of the monosynaptic basins $\mathrm{V}\left(\mathrm{C}_{7}\right)$ and $\mathrm{V}\left(\mathrm{C}_{8}\right)$ into a new disynaptic basin $\mathrm{V}\left(\mathrm{C}_{7}-\mathrm{C}_{8}\right)$, integrating to $1.24 \overline{\mathrm{e}}$, in which belongs to the cusp $\mathrm{C}$ catastrophe. The disynaptic basin $\mathrm{V}\left(\mathrm{C}_{7}-\mathrm{C}_{8}\right)$ belongs to the $\mathrm{C}_{7}-\mathrm{C}_{8}$ sigma bond and the corresponding population increases to $1.81 \overline{\mathrm{e}}$ along the SSD III.

The electrocyclic reaction pathway can be characterized by 3 SSDs associated to the sequence of catastrophes $\mathrm{C}_{8} \mathrm{H}_{8}$ (2): 3-[F $\left.\mathrm{F}^{\dagger} \mathrm{F}^{\dagger}\right] \mathrm{C}-0$ : $\mathrm{C}_{8} \mathrm{H}_{8}(\mathbf{3})$.

The bifurcation diagram of ELF localization domains for the transition state TS2 associated with the electrocyclic reaction is sketched in Figure 10. 


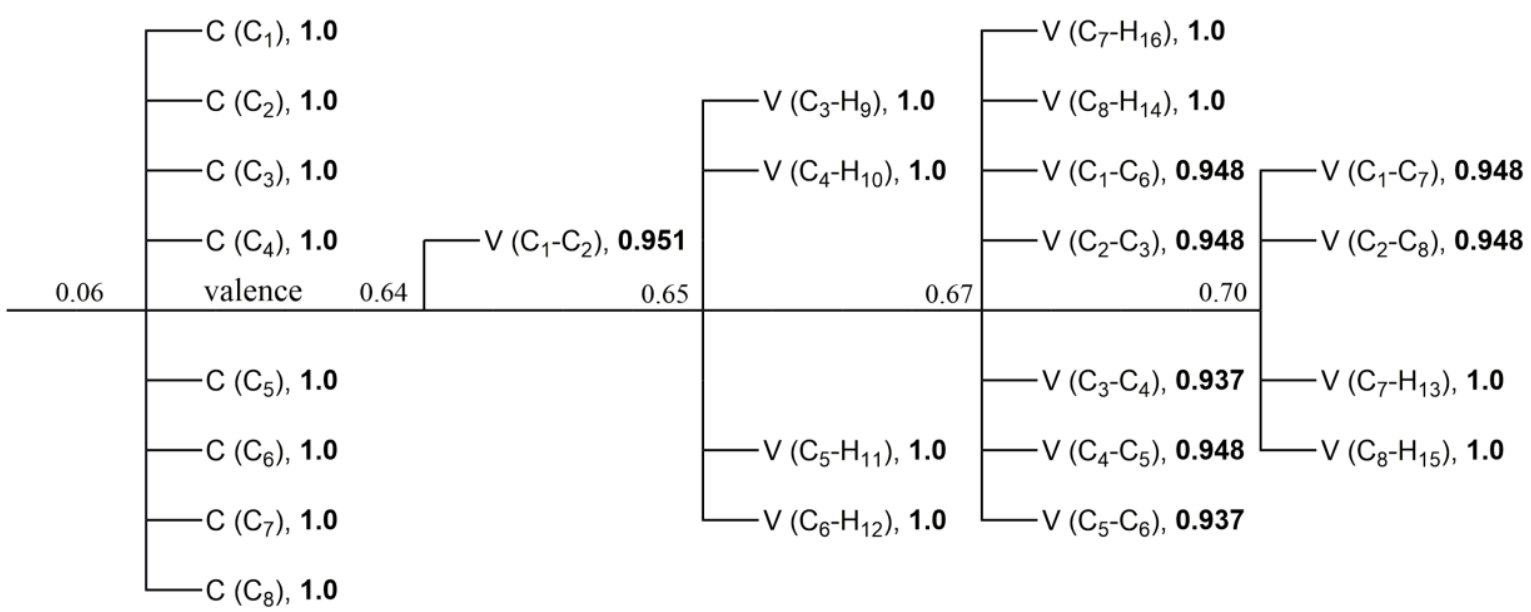

Figure 10. Reduction tree diagrams of ELF localization domains for the transition state belonging to the electrocyclic reaction.

ELF basin domains of TS2 can be divided to eight core attractors, eight protonated disynaptic attractors, and eight disynaptic attractors. After the core-valence separation at ELF value $\eta(\mathbf{r})=$ 0.06 , the valence domain undergoes a second splitting into a disynaptic attractor $\mathrm{V}\left(\mathrm{C}_{1}-\mathrm{C}_{2}\right)$ at ELF value $\eta(\mathbf{r})=0.64$, in which bifurcation immediately followed at ELF value $\eta(\mathbf{r})=0.65$ by detachment of four protonated disynaptic attractors $\mathrm{V}\left(\mathrm{C}_{3}-\mathrm{H}_{9}\right), \mathrm{V}\left(\mathrm{C}_{4}-\mathrm{H}_{10}\right), \mathrm{V}\left(\mathrm{C}_{5}-\mathrm{H}_{11}\right)$, and $\mathrm{V}$ $\left(\mathrm{C}_{6}-\mathrm{H}_{12}\right)$. The next bifurcation at ELF value $\eta(\mathbf{r})=0.67$, detaches two protonated disynaptic attractors $\mathrm{V}\left(\mathrm{C}_{7}-\mathrm{H}_{16}\right)$ and $\mathrm{V}\left(\mathrm{C}_{8}-\mathrm{H}_{14}\right)$; and five disynaptic attractors $\left(\mathrm{C}_{1}-\mathrm{C}_{6}\right), \mathrm{V}\left(\mathrm{C}_{2}-\mathrm{C}_{3}\right), \mathrm{V}$ $\left(\mathrm{C}_{3}-\mathrm{C}_{4}\right), \mathrm{V}\left(\mathrm{C}_{4}-\mathrm{C}_{5}\right)$, and $\mathrm{V}\left(\mathrm{C}_{5}-\mathrm{C}_{6}\right)$. Finally, at ELF value $\eta(\mathbf{r})=0.70$ the residual domain is split into two protonated disynaptic attractors $\mathrm{V}\left(\mathrm{C}_{7}-\mathrm{H}_{13}\right)$ and $\mathrm{V}\left(\mathrm{C}_{8}-\mathrm{H}_{15}\right)$; and two disynaptic attractors $\mathrm{V}\left(\mathrm{C}_{1}-\mathrm{C}_{7}\right)$ and $\mathrm{V}\left(\mathrm{C}_{2}-\mathrm{C}_{8}\right)$.

Color-filled maps of the electron localization function in the molecular plane defined by plane of the $\mathrm{C}_{2}-\mathrm{C}_{8}-\mathrm{C}_{7}$ for compound 2, TS2, compound 3, and critical points along the reaction coordinate between the SSDs that topologically characterize the molecular mechanism are presented in Figure 11. Color-filled maps of the ELF indicate that at $\mathbf{P}_{2}$ point electron is located between $\mathrm{C}_{7}$ and $\mathrm{C}_{8}$ atoms with the ELF value $\sim 0.80$ which is associated to the formation of new covalent bond between $\mathrm{C}_{7}$ and $\mathrm{C}_{8}$ centers. During the SSD III formation of $\mathrm{C}_{7}-\mathrm{C}_{8}$ is completed and its ELF value reaches to 1 for compound 3 . 

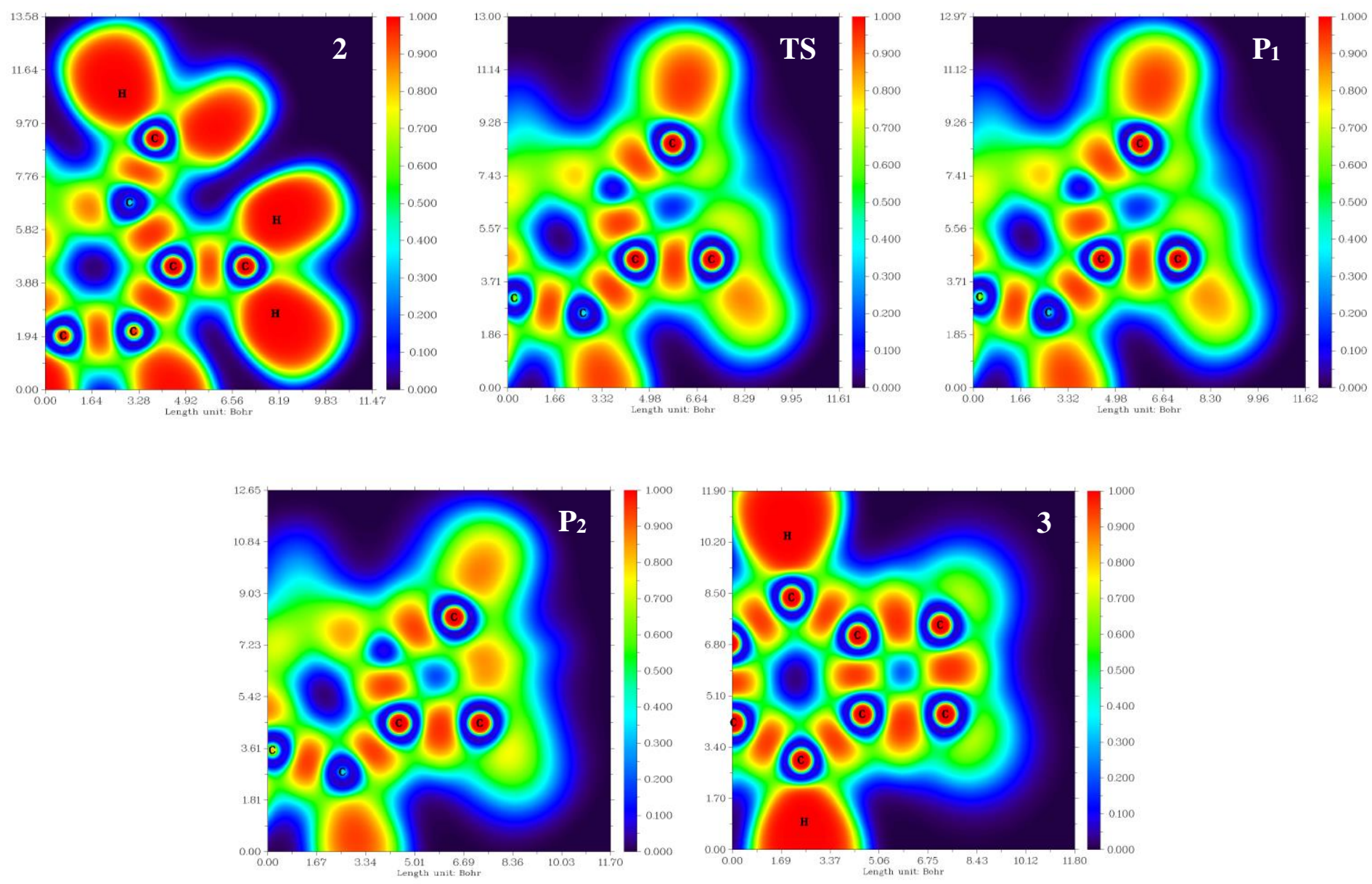

Figure 11. Color-filled maps of the electron localization function in the molecular plane defined by plane of the $\mathrm{C}_{2}-\mathrm{C}_{8}-\mathrm{C}_{7}$ for intermediate o-quinodimethane 2 , TS, selected points separating the SSDs along the reaction coordinate, and product of electrocyclic reaction. The ELF values [0 to 1] are mapped on a blue-green-red color scale indicated on the right of each representation. Blue and red colors indicate respectively no electron and high electron localization.

\section{Summary and concluding remarks}

The kinetics and mechanisms of cheletropic extrusion of 1,3-dihydroisothianaphthene-2,2dioxide and electrocyclic reaction of o-quinodimethane were computationally investigated using density functional theory along with the M06-2X exchange-correlation functional and the augcc-pVTZ basis set. Unimolecular rate coefficients were calculated at the high pressure limit by means of canonical transition state theory (CTST). Their pressure dependence has been investigated by means of statistical Rice-Ramsperger-Kassel-Marcus (RRKM) theory in the 
pressure range $10^{-7}-10^{7}$ atm and at experimentally employed temperatures 733,833 , 943, and 1043 K. Fall-off regimes generated by RRKM theory show that at the temperatures 943 and 1043 $\mathrm{K}$, the high pressure limit of rate constant is reached near $10 \mathrm{~atm}$ for the cheletropic extrusion. Therefore, transition state theory slightly breaks down to estimate reaction coefficient of cheletropic extrusion at temperatures higher than $943 \mathrm{~K}$, demonstrating the importance of incorporating pressure dependence into kinetics modeling. The RRKM results indicate that the cheletropic extrusion and electrocyclic reaction require energy barriers of 171.37 and 122.25 $\mathrm{kJ} / \mathrm{mol}$ to be overcome at ambient pressure and over the temperature range of 733-1043 K. According to an ELF topological analysis, the cheletropic extrusion and electrocyclic reaction take place respectively along 7 and 3 topologically differentiated SSDs, associated to the

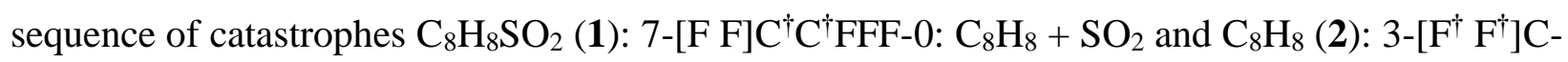
0: $\mathrm{C}_{8} \mathrm{H}_{8}$ (3). Along the cheletropic extrusion pathway, breaking of the $\mathrm{C}_{7}-\mathrm{S}$ and $\mathrm{C}_{8}-\mathrm{S}$ begins respectively at $\mathrm{Rx}=-2.7434 \mathrm{amu}^{1 / 2} \mathrm{Bohr}$ and $\mathrm{Rx}=-1.7458 \mathrm{amu}^{1 / 2} \mathrm{Bohr}$; and formation of the sulfur dioxide is completed at $\mathrm{Rx}=-0.2494 \mathrm{amu}^{1 / 2}$ Bohr. In this reaction, the saddle point is formed when the critical changes are completed, implying the retarded transition state. Along the electrocyclic reaction, pseudoradical centers are generated on the terminal carbon atoms at $\mathrm{Rx}=$

$0.1474 \mathrm{amu}^{1 / 2} \mathrm{Bohr}$ and formation of new $\mathrm{C}_{7}-\mathrm{C}_{8}$ sigma bond occurs at $\mathrm{Rx}=1.6214 \mathrm{amu}^{1 / 2} \mathrm{Bohr}$ from $\mathrm{C}$ - to $\mathrm{C}$ - coupling between the pseudoradical centers. In contrast with cheletropic extrusion, the transition state involves to the electrocyclic reaction is formed before critical changes indicating an advanced transition state.

\section{References:}

[1] K.M. Christoffel, J.M. Bowman, RRKM theory beyond the separable harmonic approximation: The $\mathrm{HCO}_{2} \rightarrow \mathrm{H}+\mathrm{CO}_{2}$ unimolecular decomposition, J. Phys. Chem. A 103 (1999) 3020-3030.

[2] W.J. Moore, Physical Chemistry, PRENTICE-HALL, INC., USA, 1972.

[3] V. Polo, J. Andrés, A joint study based on the electron localization function and catastrophe theory of the chameleonic and centauric models for the Cope rearrangement of 1,5-hexadiene and its cyano derivatives, J. Comput. Chem. 26 (2005) 1427-1437. 
[4] S. Berski, J. Andrés, B. Silvi, L.R. Domingo, New findings on the Diels-Alder reactions. An analysis based on the bonding evolution theory, J. Phys. Chem. A 110 (2006) 13939-13947.

[5] A.D. Becke, K.E. Edgecombe, A simple measure of electron localization in atomic and molecular systems, J. Chem. Phys. 92 (1990) 5397-5403.

[6] B. Silvi, A. Savin, Classification of chemical bonds based on topological analysis of electron localization functions, Nature 371 (1994) 683-686.

[7] R. Thom, Stabilité Structurelle et Morphogenèse, $2^{\text {nd }}$ ed., Paris, 1977.

[8] X. Krokidis, S. Noury, B. Silvi, Characterization of elementary chemical processes by catastrophe theory, J. Phys. Chem. A 101 (1997) 7277-7282.

[9] R.B. Woodward, R. Hoffmann, The conservation of orbital symmetry, Angew. Chem. Int. Ed Engl. 8 (1969) 781-853.

[10] S. Berski, J. Andrés, B. Silvi, L.R. Domingo, The joint use of catastrophe theory and electron localization function to characterize molecular mechanisms. A density functional study of the Diels-Alder reaction between ethylene and 1,3-butadiene, J. Phys. Chem. A 107 (2003) 6014-6024.

[11] L.R. Domingo, State of the art of the bonding changes along the Diels-Alder reaction between butadiene and ethylene: Refuting the pericyclic mechanism, Organic Chem. Curr. Res. 2 (2013) 120.

[12] L.R. Domingo, Why Diels-Alder reactions are non-concerted processes?, J. Chil. Chem. Soc. 59 (2014) 2615-2618.

[13] L.R. Domingo, M.J. Aurell, P. Pérez, The mechanism of ionic Diels-Alder reactions. A DFT study of the oxa-Povarov reaction, RSC Adv. 4 (2014) 16567-16577.

[14] L.R. Domingo, M.J. Aurell, J.A. Sáez, S.M. Mekelleche, Understanding the mechanism of the Povarov reaction. A DFT study, RSC Adv. 4 (2014) 25268-25278.

[15] L.R. Domingo, A new C-C bond formation model based on the quantum chemical topology of electron density, RSC Adv. 4 (2014) 32415-32428.

[16] L.R. Domingo, E. Chamorro, P. Pérez, Understanding the mechanism of non-polar DielsAlder reactions. A comparative ELF analysis of concerted and stepwise diradical mechanisms, Org. Biomol. Chem. 8 (2010) 5495-5504 
[17] L.R. Domingo, P. Pérez, J.A. Sáez, Origin of the synchronicity in bond formation in polar Diels-Alder reactions: an ELF analysis of the reaction between cyclopentadiene and tetracyanoethylene, Org. Biomol. Chem. 10 (2012) 3841-3851.

[18] L.R. Domingo, P. Pérez, J.A. Sáez, Understanding the regioselectivity in hetero Diels-Alder reactions. An ELF analysis of the reaction between nitrosoethylene and 1-vinylpyrrolidine, Tetrahedron 69 (2013) 107-114.

[19] L.R. Domingo, P. Pérez, A quantum chemical topological analysis of the $\mathrm{C}-\mathrm{C}$ bond formation in organic reactions involving cationic species, Phys. Chem. Chem. Phys. 16 (2014) 14108-14115.

[20] V. Polo, J. Andrés, S. Berski, L.R. Domingo, B. Silvi, Understanding reaction mechanisms in organic chemistry from catastrophe theory applied to the electron localization function topology, J. Phys. Chem. A 112 (2008) 7128-7136.

[21] M. Ríos-Gutiérrez, P. Pérez, L.R. Domingo, A bonding evolution theory study of the mechanism of [3+2] cycloaddition reactions of nitrones with electron-deficient ethylenes, RSC Adv. 5 (2015) 58464-58477.

[22] W. Benchouk, S.M. Mekelleche, M.J. Aurell, L.R. Domingo, Understanding the regio- and chemoselective polar [3+2] cycloaddition of the Padwa carbonyl ylides with $\alpha$-methylene ketones. A DFT study, Tetrahedron 65 (2009) 4644-4651.

[23] L.R. Domingo, M. Ríos-Gutiérrez, P. Pérez, A new model for C-C bond formation processes derived from the Molecular Electron-Density Theory in the study of the mechanism of [3+2] cycloaddition reactions of carbenoid nitrile ylides with electron-deficient ethylenes, Tetrahedron 72 (2016) 1524-1532.

[24] A.K. Nacereddine, C. Sobhi, A. Djerourou, M. Ríos-Gutiérrez, L.R. Domingoc, Nonclassical $\mathrm{CH} / \mathrm{O}$ hydrogen-bond determining the regio- and stereoselectivity in the $[3+2]$ cycloaddition reaction of (Z)-C-phenyl-Nmethylnitrone with dimethyl 2benzylidenecyclopropane-1,1-dicarboxylate. A topological electron-density study, RSC Adv. 5 (2015) 99299-99311.

[25] J.C. Santos, J. Andres, A. Aizman, P. Fuentealba, V. Polo, A theoretical study on the reaction mechanism for the Bergman cyclization from the perspective of the electron localization function and catastrophe theory, J. Phys. Chem. A 109 (2005) 3687-3693. 
[26] L.R. Domingo, P. Pérez, J.A. Sáez, Understanding C-C bond formation in polar reactions. An ELF analysis of the Friedel-Crafts reaction between indoles and nitroolefins, RSC Adv. 3 (2013) 7520-7528.

[27] L.R. Domingo, M. Ríos-Gutiérrez, J.A. Sáez, Unravelling the mechanism of the keteneimine Staudinger reaction. An ELF quantum topological analysis, RSC Adv. 5 (2015) 3711937129.

[28] L.R. Domingo, J.A. Sáez, Understanding the selectivity in the formation of d-lactams vs. blactams in the Staudinger reactions of chloro-cyan-ketene with unsaturated imines. A DFT study, RSC Adv. 4 (2014) 58559-58566.

[29] L.R. Domingo, M.J. Aurell, P. Pérez, Understanding the polar mechanism of the ene reaction. A DFT study, Org. Biomol. Chem. 12 (2014) 7581-7590.

[30] P. Pérez, L.R. Domingo, A DFT study of inter- and intramolecular aryne ene reactions, Eur. J. Org. Chem. 2015 (2015) 2826-2834.

[31] V. Polo, L.R. Domingo, J. Andrés, Better understanding of the ring-cleavage process of cyanocyclopropyl anionic derivatives. A theoretical study based on the electron localization function, J. Org. Chem. 71 (2006) 754-762.

[32] J.C. Santos, V. Polo, J. Andrés, An electron localization function study of the trimerization of acetylene: Reaction mechanism and development of aromaticity, Chem. Phys. Lett. 406 (2005) 393-397.

[33] L.R. Domingo, M. Ríos-Gutiérrez, P. Pérez, A DFT study of the ionic [2+2] cycloaddition reactions of keteniminium cations with terminal acetylenes, Tetrahedron 71 (2015) 2421-2427.

[34] L.R. Domingo, M. Ríos-Gutiérrez, P. Pérez, E. Chamorro, Understanding the [2n+2n] reaction mechanism between a carbenoid intermediate and $\mathrm{CO}_{2}$, Mol. Phys. 114 (2016) 13741391.

[35] I. Fleming, Molecular Orbitals and Organic Chemical Reactions, John Wiley \& Sons Ltd., UK, 2009.

[36] E. Zahedi, M. Mozaffari, F. Shahsavar, A. Shiroudi, M.S. Deleuze, Understanding the kinetics and mechanism of thermal cheletropic elimination of $\mathrm{N}_{2}$ from (2,5-dihydro-1H-pyrrol-1ium-1-ylidene) amide using RRKM and ELF theories, Res. Chem. Intermed. (Accepted for Publication). 
[37] M.P. Cava, A.A. Deana, Condensed cyclobutane aromatic compounds. VI. The pyrolysis of 1,3-dihydroisothianaphthene-2,2-dioxide: A new synthesis of benzocyclobutene, J. Am. Chem. Soc. 81 (1959) 4266-4268.

[38] H. Eyring, The activated complex and the absolute rate of chemical reactions, Chem. Rev. 17 (1935) 65-77.

[39] A. Fernandez-Ramos, B.A. Ellingson, B.C. Garrett, D.G. Truhlar, Variational transition state theory with multidimensional tunneling, Rev. Comput. Chem. 23 (2007) 125-232.

[40] D.G. Truhlar, B.C. Garrett, S.J. Klippenstein, Current status of transition-state theory, J. Phys. Chem. 100 (1996) 12771-12800.

[41] W. Forst, Unimolecular rate theory test in thermal reactions, J. Phys. Chem. 76 (1972) 342348.

[42] W. Forst, Unimolecular Reactions. A Concise Introduction, C. U. Press, Cambridge, 2003.

[43] K.A. Holbrook, M.J. Pilling, S.H. Robertson, Unimolecular Reactions, $2^{\text {nd }}$ ed., John Wiley \& Sons, Inc., Chichester, 1996.

[44] P.J. Robinson, K.A. Holbrook, Unimolecular Reactions, Wiley-Interscience, New York, 1972.

[45] X. Li, M.J. Frisch, Energy-represented direct inversion in the iterative subspace within a hybrid geometry optimization method, J. Chem. Theory Comput. 2 (2006) 835-839.

[46] Y. Zhao, D.G. Truhlar, The M06 suite of density functionals for main group thermochemistry, thermochemical kinetics, noncovalent interactions, excited states, and transition elements: Two new functionals and systematic testing of four M06 functionals and twelve other functionals, Theor. Chem. Acc. 120 (2008) 215-241.

[47] Y. Zhao, D.G. Truhlar, Density functionals with broad applicability in chemistry, Acc. Chem. Res. 41 (2008) 157-167.

[48] T.H. Dunning-Jr., Gaussian basis sets for use in correlated molecular calculations. I. The atoms boron through neon and hydrogen, J. Chem. Phys. 90 (1989) 1007-1023.

[49] E.D. Glendening, A.E. Reed, J.E. Carpenter, F. Weinhold, NBO Version 3.1.

[50] M.J. Frisch, G.W. Trucks, H.B. Schlegel, G.E. Scuseria, M.A. Robb, J.R. Cheeseman, G. Scalmani, V. Barone, B. Mennucci, G.A. Petersson, H. Nakatsuji, M. Caricato, X. Li, H.P. Hratchian, A.F. Izmaylov, J. Bloino, G. Zheng, J.L. Sonnenberg, M. Hada, M. Ehara, K. Toyota, R. Fukuda, J. Hasegawa, M. Ishida, T. Nakajima, Y. Honda, O. Kitao, H. Nakai, T. Vreven, J.A. 
Montgomery-Jr., J.E. Peralta, F. Ogliaro, M. Bearpark, J.J. Heyd, E. Brothers, K.N. Kudin, V.N. Staroverov, T. Keith, R. Kobayashi, J. Normand, K. Raghavachari, A. Rendell, J.C. Burant, S.S. Iyengar, J. Tomasi, M. Cossi, N. Rega, J.M. Millam, M. Klene, J.E. Knox, J.B. Cross, V. Bakken, C. Adamo, J. Jaramillo, R. Gomperts, R.E. Stratmann, O. Yazyev, A.J. Austin, R. Cammi, C. Pomelli, J.W. Ochterski, R.L. Martin, K. Morokuma, V.G. Zakrzewski, G.A. Voth, P. Salvador, J.J. Dannenberg, S. Dapprich, A.D. Daniels, O. Farkas, J.B. Foresman, J.V. Ortiz, J. Cioslowski, D.J. Fox, Gaussian, Inc., Wallingford CT, Gaussian 09, Revision D.01, 2013.

[51] S. Canneaux, F. Bohr, E. Henon, KiSThelP: Kinetic and Statistical Thermodynamical Package, 2014.

[52] M.D. Allendorf, T.M. Besmann, R.J. Kee, M.T. Swihart, Chemical Vapour Deposition: Precursors, Processes and Applications, $1^{\text {st }}$ ed., The Royal Society of Chemistry, UK, 2009, Chap 3, 93-157.

[53] C. Eckart, The penetration of a potential barrier by electrons, Phys. Rev. 35 (1930) 13031309.

[54] R.L. Brown, A method of calculating tunneling corrections for Eckart potential barriers, J. Res. Natl. Bur. Stand. 86 (1981) 357-359.

[55] J.I. Steinfeld, J.S. Francisco, W.L. Hase, Chemical Kinetics and Dynamics, Prentice-Hall, Englewood Cliffs, NJ, 1999.

[56] H. Eyring, S.H. Lin, S.M. Lin, Basic Chemical Kinetics, Wiley, New York, 1980.

[57] F.M. Mourits, F.H.A. Rummens, A critical evaluation of Lennard-Jones and Stockmayer potential parameters and of some correlation methods, Can. J. Chem. 55 (1977) 3007-3020.

[58] CHEMKIN-PRO 15131, Reaction Design: San Diego, 2013.

[59] S. Canneaux, F. Bohr, E. Henon, KiSThelP: A program to predict thermodynamic properties and rate constants from quantum chemistry results, J. Comput. Chem. 35 (2014) 82-93.

[60] S. Noury, X. Krokidis, F. Fuster, B. Silvi, TopMod package, 1997.

[61] T. Lu, F. Chen, Multiwfn: A multifunctional wavefunction analyzer, J. Comput. Chem. 33 (2012) 580-592.

[62] D. Marx, A. Savin, Topological bifurcation analysis: Electronic structure of $\mathrm{CH}^{+5}$, Angen. Chem. Int. Ed. Engl. 36 (1997) 2077-2080. 
[63] Y. Grin, A. Savin, B. Silvi, The ELF Perspective of chemical bonding, in: G. Frenking, S. Shaik (Eds.), The Chemical Bond : Fundamental Aspects of Chemical Bonding, Wiley-VCH Verlag GmbH \& Co. KGaA., USA, 2014.

[64] A. Savin, B. Silvi, F. Colonna, Topological analysis of the electron localization function applied to delocalized bonds, Can. J. Chem. 74 (1996) 1088-1096.

[65] Computational Chemistry Comparison and Benchmark Database, Precomputed Vibrational Scaling Factors, http://cccbdb.nist.gov/vibscalejust.asp.

[66] R. Jasiński, E. Dresler, A desulfonylation process as easy route for synthesis of 1,4-dinitro1,3-dienes: Mechanistic study, Phosphorus, Sulfur Silicon Relat. Elem. 191 (2016) 311-315. 